Synthesis

\title{
Coupled human and natural systems approach to wildlife research and conservation
}

\author{
Neil H. Carter ${ }^{1}$, Andrés Viña $^{2}$, Vanessa Hull $^{2}$, William J. McConnell $^{2}$, William Axinn $^{3}$, Dirgha Ghimire $^{3}$ and Jianguo Liu $^{2}$
}

\begin{abstract}
Conserving wildlife while simultaneously meeting the resource needs of a growing human population is a major sustainability challenge. As such, using combined social and environmental perspectives to understand how people and wildlife are interlinked, together with the mechanisms that may weaken or strengthen those linkages, is of utmost importance. However, such integrated information is lacking. To help fill this information gap, we describe an integrated coupled human and natural systems (CHANS) approach for analyzing the patterns, causes, and consequences of changes in wildlife population and habitat, human population and land use, and their interactions. Using this approach, we synthesize research in two sites, Wolong Nature Reserve in China and Chitwan National Park in Nepal, to explicate key relationships between people and two globally endangered wildlife conservation icons, the giant panda and the Bengal tiger. This synthesis reveals that local resident characteristics such as household socioeconomics and demography, as well as community-level attributes such as resource management organizations, affect wildlife and their habitats in complex and even countervailing ways. Human impacts on wildlife and their habitats are in turn modifying the suite of ecosystem services that they provide to local residents in both sites, including access to forest products and cultural values. These interactions are further complicated by human and natural disturbance (e.g., civil wars, earthquakes), feedbacks (including policies), and telecouplings (socioeconomic and environmental interactions over distances) that increasingly link the focal systems with other distant systems. We highlight several important implications of using a CHANS approach for wildlife research and conservation that is useful not only in China and Nepal but in many other places around the world facing similar challenges.
\end{abstract}

Key Words: complex systems; conservation; endangered species; interdisciplinary science; wildlife science

\section{INTRODUCTION}

Coupled human and natural systems (CHANS; or coupled social-ecological systems [Walker et al. 2004] or coupled humanenvironment systems [Turner et al. 2003]) are integrated and complex systems in which humans and nature interact with one another (Liu et al. 2007a). Wildlife are important components of CHANS because they interact with humans in numerous complex ways in today's increasingly human-influenced world. Globally, the continuing conversion of natural ecosystems to areas used intensively by humans has greatly reduced wildlife habitat, leading to an "extinction crisis" (Hoekstra et al. 2005:23). The disappearance of wildlife and their habitats entails the degradation of life-sustaining ecosystem services such as the availability of medicines, control of pests and diseases, and provision of clean water and air (De Groot et al. 2002). Moreover, because people worldwide value nature for numerous reasons (e.g., aesthetic, cultural, religious, economic, educational), the loss of wildlife and their habitats diminishes humans' quality of life (Manfredo et al. 2009, Carter et al. 2012a).

Given these challenges, an integrated CHANS approach for understanding human-wildlife interactions is of utmost importance. Although interactions between people and wildlife have been examined for some time, most studies are compartmentalized within disciplines. There is little knowledge on how people and wildlife are interlinked, across space and through time, from combined social and environmental perspectives, together with the mechanisms that may weaken or strengthen those linkages. Thus, to reach broad, generalizable insights about wildlife dynamics, findings from sites with different ecological, socioeconomic, political, demographic, and/or cultural settings need to be synthesized. Such cross-site syntheses will have significant scientific value and facilitate knowledge exchange among multiple stakeholders, including local residents, managers of natural resources, policy makers, tourists, and researchers. This is critical for developing an array of policies and interventions that improve human wellbeing while sustaining wildlife populations and their habitats.

Here, we describe an integrated CHANS approach for analyzing the patterns, causes, and consequences of changes in wildlife population and habitat, human population and land use (Rindfuss et al. 2008), and their interactions (Linderman et al. 2005a, Bearer et al. 2008). Using this approach, we synthesize research in two globally important sites, the Wolong Nature Reserve (hereafter Wolong) in China and the Chitwan National Park (hereafter Chitwan) in Nepal, to explicate key relationships between people and two endangered wildlife conservation icons, the giant panda (Ailuropoda melanoleuca) and the Bengal tiger (Panthera tigris tigris). Wolong and Chitwan are flagship protected areas located within global biodiversity hotspots (Myers et al. 2000) and support important populations of pandas and tigers, respectively. Because both of these species are confined to a fraction of the geographic ranges they once occupied, protecting their remaining habitat is crucial for their long-term survival. Thus, both of these protected areas are part of national and international programs to sustain populations of these conservation icons. Yet, in both sites, growing local human populations continue to pursue natural resource-based livelihoods. We provide a foundation for a cross-site synthesis by integrating information about CHANS processes in both sites. Through the synthesis, we highlight several important implications of using a CHANS approach for wildlife 
conservation that is useful not only in China (Liu 2010) and Nepal, but in many other places around the world facing similar challenges.

\section{THE COUPLED HUMAN AND NATURAL SYSTEMS APPROACH}

Inherently integrative in nature, the CHANS approach brings together theoretical and analytical techniques from diverse disciplines, including those from ecological and social sciences, to understand the nuances of such complex systems (Turner et al. 2003, Walker et al. 2004, Liu et al. 2007a,b, Ostrom 2009). The CHANS approach is thus well suited for understanding wildlife dynamics in human-influenced landscapes. First, by transcending a single discipline, the approach can account for the patterns and processes that link people and their activities with wildlife and their habitats. Second, rather than focusing on unidirectional relationships, the approach can identify key relationships and feedbacks between people and wildlife. Third, the approach facilitates understanding of cross-scale (e.g., spatial, temporal, and organizational) interactions between people and wildlife. Thus, the CHANS approach can better clarify relationships between people and wildlife and consequently help to prevent further habitat loss and wildlife population decline in the face of synergistic and increasingly complex threats (e.g., overexploitation of natural resources, climate change) while simultaneously responding to growing human aspirations for improved quality of life.

We conceptualize each of the focal sites as a coupled system consisting of two main subsystems, the human subsystem and the natural subsystem, whose detailed operation is made evident through appropriate disciplinary analyses. For our purposes, the human subsystem comprises communities and local residents, and the natural subsystem comprises wildlife and the land cover characterizing their habitat (Fig. 1). Telecouplings (i.e., socioeconomic and environmental interactions over distances, Liu et al. 2013) link the focal coupled system to other distant coupled systems (Fig. 1). The characteristics of each of these system components are interrelated and influence the characteristics of the other system components (Turner et al. 2003, Walker et al. 2004, Liu et al. 2007b, Ostrom 2009). For example, collection of fuelwood and grasses by local residents can change land cover composition and structure and disrupt the spatial and temporal distribution of wildlife. Community organizations such as forest user group committees can encourage reforestation, which in turn provides more income for local residents. Networks of people in the community connected through "weak ties" (Granovetter 1973) can shape and be shaped by policies and norms that influence many aspects of the daily lives of local residents. Wildlife can change forest characteristics through browsing and might decrease household income by eating crops and/or livestock. The interactions within and among each of these components influence and are influenced by telecouplings such as tourism and migration, among many others (Fig. 1). For example, labor demands by urban centers generate rural-urban migration, which can reduce the proportion of young people living in a rural area. Fewer young people collecting natural resources from nearby forests can slow rates of wildlife habitat degradation.

Worldviews differ markedly with respect to the way people understand the world, and particularly, what it is to be human and the role humans play in that world (Ingold 2000, Descola and Pálsson 2013). The CHANS approach is intended neither to perpetuate one worldview (e.g., people separate from nature) over another, nor to ignore the perceptions and knowledge of certain groups of people. Rather, it is intended to serve as a pragmatic, heuristic tool for analyzing interrelationships between people and the environment, seeking to reunite the scientific traditions focusing on particular subsystems. The CHANS framework emphasizes that the human and natural components are coupled rather than separate. Furthermore, it emphasizes feedbacks between the components. Collaboration among a range of stakeholders helps CHANS projects build alternative hypotheses and understandings of complex issues.

Fig. 1. General conceptual diagram of dynamic (changing across space and time) and reciprocal relationships between main components of coupled human and natural systems (CHANS) with respect to wildlife research and conservation. Human-nature interactions (wildlife impacts on people and vice versa) are weakened and/or strengthened by a number of factors and processes such as disturbances, policies, and feedbacks. Telecoupling processes (socioeconomic and environmental interactions over distances) link the focal CHANS to other distant CHANS. For simplicity, interrelationships among subsystem characteristics are not shown. Dotted lines indicate that system boundaries are permeable. This framework has similarities with the framework illustrated in Ostrom (2009) for broadly analyzing social-ecological systems.

\section{COUPLED HUMAN AND NATURAL SYSTEMS}

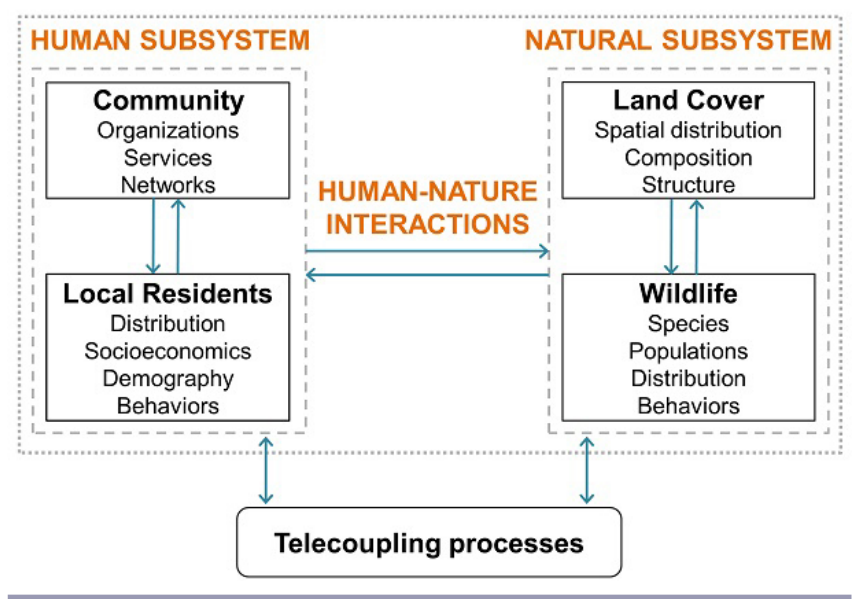

\section{COMPARATIVE EXAMPLE OF COUPLED HUMAN AND NATURAL SYSTEMS RESEARCH}

We use the CHANS approach to understand key interactions between people and wildlife in Wolong and Chitwan (Fig. 2) and as a guiding principle for synthesizing findings across the two sites. These two protected areas are ideal for synthesizing humanwildlife interactions because long-term empirical and interdisciplinary data are available. This allows us to obtain a holistic perspective of the various interconnections among the components of the CHANS in each site (Table 1). Moreover, the dynamics between humans and wildlife in both sites, as well as their interactions, are similar to many other sites around the world, including some of the 170,000 protected areas that 
Table 1. Major characteristics of key components in coupled human and natural systems in Wolong, China, and Chitwan, Nepal. We focused on the dynamics of these coupled systems as they pertain specifically to the globally endangered giant panda in Wolong and Bengal tiger in Chitwan. The manner in which disturbances, conservation policies, and feedbacks weaken and/or strengthen humannature interactions (wildlife impacts on people and vice-versa) in both sites are described in the text.

\begin{tabular}{|c|c|c|c|}
\hline \multicolumn{4}{|l|}{ System } \\
\hline Component & $\begin{array}{l}\text { Major } \\
\text { characteristics }\end{array}$ & Wolong (China) & Chitwan (Nepal) \\
\hline \multicolumn{4}{|l|}{ Human subsystem } \\
\hline \multirow[t]{3}{*}{ Community } & Organizations & Local government, reserve administration & $\begin{array}{l}\text { National park managing department, community } \\
\text { forest user groups }\end{array}$ \\
\hline & Services & $\begin{array}{l}\text { Roads, schools, hospitals, markets, employment } \\
\text { centers (e.g., tourist lodges), hydropower, post- } \\
\text { earthquake aid }\end{array}$ & $\begin{array}{l}\text { Roads, schools, hospitals, markets, employment } \\
\text { centers (e.g., tourist lodges), agricultural co- } \\
\text { operatives }\end{array}$ \\
\hline & Networks & $\begin{array}{l}\text { Kin relationships in large families (including out- } \\
\text { migrants to distant places), cross-department } \\
\text { government partnerships, business partnerships }\end{array}$ & $\begin{array}{l}\text { Kin relationships in large families (including out- } \\
\text { migrants to distant places), cross-scale } \\
\text { institutional collaborations (park managers and } \\
\text { community forest users), business partnerships }\end{array}$ \\
\hline \multirow[t]{4}{*}{ Local residents } & Distribution & $\begin{array}{l}\text { Within the reserve, close to the main road and } \\
\text { water sources }\end{array}$ & $\begin{array}{l}\text { Outside the park, concentrated mostly around the } \\
\text { main city }\end{array}$ \\
\hline & Socioeconomics & $\begin{array}{l}\text { Mostly rural poor; income earned mainly through } \\
\text { farming (growing crops and rearing livestock), } \\
\text { entrepreneurship (e.g., tourist venture, } \\
\text { transportation business), and construction }\end{array}$ & $\begin{array}{l}\text { Mostly rural poor; income earned mainly through } \\
\text { farming (growing crops and rearing livestock), } \\
\text { entrepreneurship (e.g., tourist venture, retail shop), } \\
\text { construction, and government employment }\end{array}$ \\
\hline & Demography & Mainly ethnic minorities (Tibetan and Qiang) & $\begin{array}{l}\text { Mainly higher caste Hindus, but also Terai Tibeto- } \\
\text { Burmese (Indigenous), hill Tibeto-Burmese, and } \\
\text { lower caste Hindus }\end{array}$ \\
\hline & Behaviors & $\begin{array}{l}\text { Farming, timber harvesting, fuelwood and } \\
\text { medicinal herb collection, hunting, infrastructure } \\
\text { construction, participation in conservation } \\
\text { programs }\end{array}$ & $\begin{array}{l}\text { Farming, timber harvesting, fuelwood and } \\
\text { medicinal herb collection, infrastructure } \\
\text { construction, participation in conservation } \\
\text { programs }\end{array}$ \\
\hline \multicolumn{4}{|l|}{ Natural subsystem } \\
\hline \multirow[t]{3}{*}{ Land cover } & $\begin{array}{l}\text { Spatial } \\
\text { distribution }\end{array}$ & $\begin{array}{l}\text { Forest found along mid-elevations, alpine region } \\
\text { in high elevations; human communities (farmland, } \\
\text { built structures) in low elevations along main road } \\
\text { running northeast to southwest through the } \\
\text { reserve's center }\end{array}$ & $\begin{array}{l}\text { Park mostly covered with forests, large grassland } \\
\text { complexes found alongside rivers; human } \\
\text { communities (farmland, built structures) surround } \\
\text { park on all sides (interspersed with few forest } \\
\text { tracts), with city just north of the park }\end{array}$ \\
\hline & Composition & $\begin{array}{l}\text { Mainly coniferous forest, deciduous broadleaf } \\
\text { forest, mixed deciduous-coniferous forest, } \\
\text { grassland above the tree line }\end{array}$ & $\begin{array}{l}\text { Deciduous forest (i.e., sal forest), mixed deciduous- } \\
\text { evergreen forest (i.e., riverine forest), grassland } \\
\text { (mostly along river banks) }\end{array}$ \\
\hline & Structure & $\begin{array}{l}\text { Topography is complex with slopes exceeding } 50^{\circ} \\
\text { with deep valleys formed by tectonic activity; } \\
\text { forests have high biodiversity and complex vertical } \\
\text { structure, with bamboo dominating the } \\
\text { understory }\end{array}$ & $\begin{array}{l}\text { Topography is relatively flat with elevations } \\
\text { ranging from } 150 \text { to } 815 \mathrm{~m} \text {; forests/grasslands have } \\
\text { high biodiversity and complex vertical structure, } \\
\text { with many different grass and shrub understory } \\
\text { species }\end{array}$ \\
\hline \multirow[t]{4}{*}{ Wildlife } & $\begin{array}{l}\text { Species } \\
\text { (charismatic } \\
\text { megafauna) }\end{array}$ & Giant panda, golden monkey, takin, snow leopard & $\begin{array}{l}\text { Bengal tiger, one-horned rhinocerus, wild } \\
\text { elephant, gharial crocodile, gaur }\end{array}$ \\
\hline & Populations & $\begin{array}{l}\text { Populations have declined in the last century; } \\
\text { giant panda and several other species are at } \\
\text { endangered status }\end{array}$ & $\begin{array}{l}\text { Populations have declined in the last century; } \\
\text { Bengal tiger and several other species are at } \\
\text { endangered status }\end{array}$ \\
\hline & Distribution & $\begin{array}{l}\text { Fragmented; giant pandas are in three distinct } \\
\text { groups (one is isolated from the other two) }\end{array}$ & $\begin{array}{l}\text { Single commingling population of Bengal tigers } \\
\text { resides in Chitwan and surrounding forests but is } \\
\text { isolated from the other two populations in Nepal }\end{array}$ \\
\hline & Behaviors & $\begin{array}{l}\text { Pandas avoid humans, prefer areas with higher } \\
\text { bamboo cover, gentle slopes, and no human } \\
\text { impacts }\end{array}$ & $\begin{array}{l}\text { Tigers prefer grasslands and connected land cover; } \\
\text { tigers avoid people by being mostly active at night }\end{array}$ \\
\hline Telecoupling & $\begin{array}{l}\text { Connections to } \\
\text { distant coupled } \\
\text { systems }\end{array}$ & $\begin{array}{l}\text { Conservation policy frameworks created outside } \\
\text { Wolong; increasing tourists from distant places; } \\
\text { rural-urban out-migration }\end{array}$ & $\begin{array}{l}\text { Conservation policy frameworks created outside } \\
\text { Chitwan; increasing tourists from distant places; } \\
\text { rural-urban out-migration }\end{array}$ \\
\hline
\end{tabular}


currently cover $12.7 \%$ of the world's land area (Bertzky et al. 2012). Therefore, results and lessons drawn from these two sites will establish a basis for extended comparative studies from which more general lessons can be drawn. In the following paragraphs, we synthesize key aspects of the natural subsystem, the human subsystem, the interactions between them, and telecoupling processes in both sites.

Fig. 2. Locations of the two focal coupled human and natural systems (CHANS) examined: Wolong Nature Reserve in China and Chitwan National Park in Nepal. Forested and cultivated areas are shown for each CHANS. The locations of many other protected areas are indicated in gray.

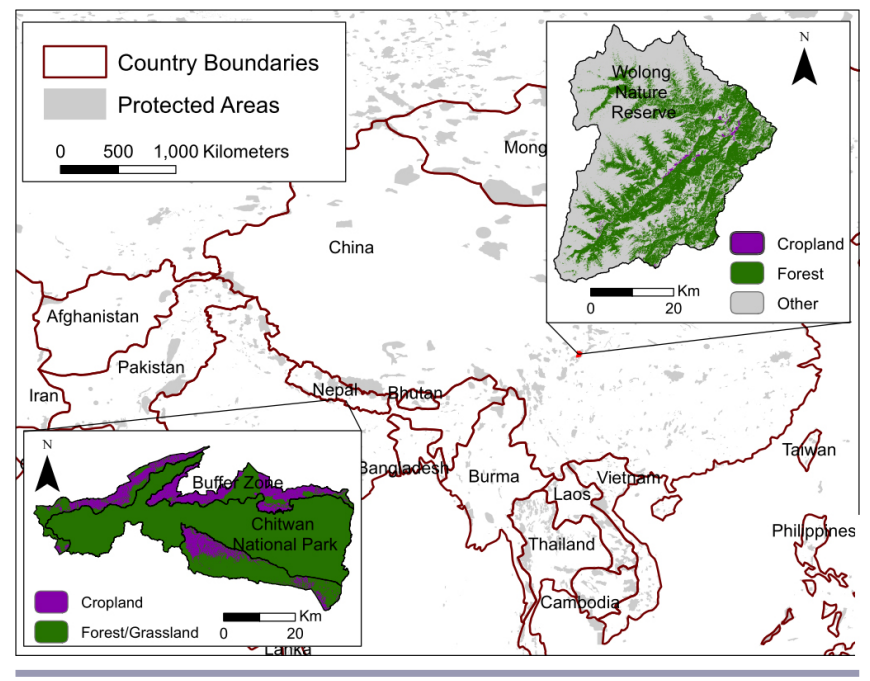

\section{NATURAL SUBSYSTEMS}

At the broadest level, characteristics of the natural subsystems in both study sites are a function of local biogeographic conditions. For example, the two study sites considered here are located in Asia, on the flanks of the Tibetan plateau: Chitwan in the Terai foothills of the Himalayas above the Indo-Gangetic Plain, and Wolong in the Qionglai Mountains above the Sichuan Basin (Tuanmu et al. 2010). Both sites comprise segments of major rivers feeding the plains below; Wolong sits astride the Pitiao River and its tributaries, and Chitwan straddles the Rapti River at its confluence with the Narayani. Despite these similarities, there are important differences in biophysical context. For example, the topography of Wolong is more rugged, with elevations ranging from 1200 to $>6200 \mathrm{~m}$ (Viña et al. 2008), whereas Chitwan lies at relatively low elevations between 150 and $815 \mathrm{~m}$ (Carter et al. 2013).

\section{Land cover}

In both sites, forests are conspicuous natural land cover (Table 1). In Wolong, forests are mainly coniferous and deciduous broadleaf at lower elevations, whereas higher elevations are characterized by subalpine coniferous forests (Tuanmu et al. 2011). These forest types have a dense understory, including bamboo species such as Bashania fabri and Fargesia robusta, which are the staple food of the giant panda (Schaller et al. 1985, Reid and $\mathrm{Hu}$ 1991, Taylor and Qin 1993). Other natural landcover types in Wolong include alpine meadows located above the tree line (Linderman et al. 2005b). In Chitwan, the forests are mainly deciduous, dominated by sal (Shorea robusta), and with some mixed deciduous/evergreen forests found mainly along river banks. Other land-cover types in Chitwan include grasslands (i.e., wooded grasslands, phantas, and floodplain grasslands; Chaudhary 1998).

\section{Wildlife}

Both sites support many endangered wildlife species (Table 1). In this synthesis, however, we focus on tigers in Chitwan and giant pandas in Wolong. Estimated at 25 animals in the late 1960s (Nepal and Weber 1995a), the tiger population in Chitwan currently consists of approximately 125 adults, constituting one of the largest commingling populations of tigers in South Asia (Karki et al. 2014). However, the Chitwan tiger population is isolated from the other two tiger populations in Nepal, which reside primarily in Bardia National Park and Suklaphanta Wildlife Reserve, west of Chitwan (Smith et al. 1998). Tigers in Chitwan prefer areas with large patches of grassland (Carter et al. 2013), which support high densities of their prey and contain important water sources (Eisenberg and Seidensticker 1976) as well as provide cover for tigers' hunting activities (Sunarto et al. 2012). Tigers also prefer contiguous patches of vegetated land cover (e.g., grasslands, sal forest) over fragmented land-cover types, likely because such areas facilitate their movement across the landscape (Carter et al. 2013).

The giant panda population in Wolong is currently estimated at 154 animals, accounting for approximately $10 \%$ of the entire wild giant panda population (Chen et al. 2012b). The distribution of pandas in Wolong is fragmented (as it is throughout their entire geographic range; Viña et al. 2010), with three distinct subpopulations, one of which is isolated from the other two, making the Wolong population at potential risk of local extinction in the future due to genetic isolation $(\mathrm{Hu} 2001)$. Coniferous forests as well as mixed coniferous and deciduous broadleaf forests with bamboo understory provide the most suitable land-cover types for pandas (Schaller et al. 1985). Pandas affect land-cover attributes in complex ways. For example, although pandas have not been observed to deplete bamboo populations via foraging, selective bamboo foraging by pandas according to different culm characteristics can affect local bamboo populations by altering bamboo age structure and regeneration patterns (Wang et al. 2007, Hull et al. 2011a). For ease of movement, pandas prefer relatively flat terrain. Pandas also prefer elevations below $\sim 3250$ $\mathrm{m}$ because there is little bamboo above that elevation (Schaller et al. 1985, Liu et al. 1999c).

\section{HUMAN SUBSYSTEMS}

The region around Wolong has been inhabited by people for centuries. Small-scale commercial logging emerged in the area in the early 20 th century. In the early 1960 s, the first road to the reserve was paved and a government forest bureau was established (Ghimire 1997). By 1965, forests covered approximately $50 \%$ of the landscape (Viña et al. 2007).

Likewise, the Chitwan Valley has been inhabited by people for centuries, though only sparsely until the early 1950s, when the Government of Nepal, with the assistance of the United States, initiated a program in the Terai to eradicate malaria and distribute land to settlers from the higher Himalayas, who were 
experiencing famine at the time (Shivakoti et al. 1999, Axinn and Ghimire 2011). The migrants rapidly transformed the dense forests of the valley into farmland (Matthews et al. 2000, Nagendra et al. 2005), with nearly one-half of the Chitwan forests converted to cultivation between 1961 and 1977 (Department of National Parks and Wildlife Conservation 1999).

\section{Local residents}

Chitwan's human population consists mostly of higher caste Hindus and also includes ethnic minority groups, including the indigenous Terai Tibeto-Burmese peoples (Table 1). Like approximately one-half of the developing-country rural population worldwide (Jazairy et al. 1992), the majority of Chitwan's residents are semi-subsistence farmers (Matthews et al. 2000, Gurung et al. 2009) who grow cereals, fruits, and vegetables. Most people raise livestock (cattle, buffalo, goats, and chickens) for consumption, transport, manure, house construction materials (e.g., dung is mixed with mud to plaster house walls and floors), and to generate cash (e.g., milk, meat, and eggs sold in markets; Sharma 1990). Except for a contingent of the Nepal Army that regularly patrols the park to deter illegal hunting and logging, no one currently resides inside the park. In 2011, approximately 580,000 local residents in $>132,000$ households were living in Chitwan district directly outside the park (Nepal Central Bureau of Statistics 2014).

In contrast, Wolong people live both nearby and within the reserve. In 2004, approximately 37,500 local residents inhabited the four townships adjoining the reserve along its eastern border (Viña et al. 2007). Rugged topography and long travel distances discourage outsiders from entering Wolong on foot, and there are no practicable roads entering the reserve. Therefore, few people living outside the reserve rely on the natural resources of the reserve as do the people living within. The area inside the reserve is currently home to approximately 5000 local residents in $>1100$ households. More than $90 \%$ of the people living inside the reserve are farmers (Table 1) who grow maize, potato, and vegetables, largely for subsistence (An et al. 2001, Viña et al. 2007). Wolong's rural population self-identifies mainly as being of Tibetan and Qiang descent, both of which are ethnic minority groups in China. They raise several kinds of livestock (e.g., pigs, cattle, yaks, horses, chickens, and goats), which are essential sources of food and income (e.g., selling pork and bacon to tourists and local restaurants; An et al. 2001).

Aside from farming, local residents in both sites engage in a number of activities that involve interaction with the natural subsystem, which are discussed below in Human-nature interactions.

\section{Communities}

Historically, most social activities of daily life in both sites were organized within the extended family. Changes in the technological and institutional contexts in Wolong and Chitwan, as with much of the world, are increasingly altering the degree to which social activities are now organized outside the family (Coleman 1994). New schools, health services, markets, wage employers, and transportation services (Table 1) continue to sprout in both sites, changing social activities, including consumption, residence, recreation, protection, socialization, procreation, and production (Ghimire 1997, Axinn and Ghimire 2011). In both sites, for example, new community organizations, services, and networks are gradually leading to a shift in production to a more commercial orientation and leading to an increase in the consumption of resources produced in distant lands (Axinn and Ghimire 2011, Bhandari 2013).

Local forests were managed by local communities in both sites prior to the nationalization of forests in China and Nepal in the 20th century (Agrawal and Ostrom 2001, Kant 2001). Since then, natural resource management decisions affecting both sites originate primarily from the regional or central governments. Wolong is managed by the Wolong Administration Bureau, which reports to both the State Forestry Administration (a central government agency) and the Forestry Department of Sichuan Province. Chitwan National Park is managed by the Department of National Parks and Wildlife Conservation (offices inside and adjacent to the park) under the Ministry of Forests and Soil Conservation (Table 1). However, a recent broad-scale process of decentralization in forest management in both China (Liu and Diamond 2005) and Nepal (Nagendra et al. 2005), mirroring a developing-world trend (Agrawal et al. 2008), has led to the reemergence of community organizations and networks that manage and monitor forests in both sites (Nagendra et al. 2005, Liu et al. 2008).

\section{HUMAN-NATURE INTERACTIONS}

We next highlight wildlife impacts on humans, human impacts on wildlife, and how these impacts are interlinked in both sites. We also investigate the role of natural and human disturbance, conservation policies, and feedbacks on both of the coupled systems. We pay particular attention to how conservation policies mediate human-wildlife interactions because policies are humanmade and therefore can be modified to influence system dynamics. Development policies also strongly influence system dynamics in both sites; however, a review of their effects is beyond the scope of this work.

\section{Wildlife impacts on humans}

In both areas, there are many families that have lived there for just one or a few generations, whereas others have lived there for hundreds of years (Ghimire 1997, McLean 1999). After such time, the day-to-day interactions with and knowledge of the wildlife and their environments has helped to shape the local human cultures. The gods of the Tharu people, an indigenous minority in Chitwan, include a large number of deities that live in the nearby forest (Müller-Böker 1991). To the Tibetan people who occupy Wolong and the surrounding areas, the mountains and the trees and animals (including pandas) that reside in them are sacred (Liu et al. 2011). The people that have arrived more recently, even if they are not accustomed to living with the wildlife where they now reside, also have strong cultural ties to the wildlife that have inhabited the broader region for a long time. For example, in the religious foundations of Buddhism and Hinduism, both of which originated in South Asia and dominate in Chitwan, animals can serve as vessels for the souls of one's ancestors (McNeely and Sochaczewski 1991). As such, respecting the forest and its animal inhabitants is important because not doing so invites tragedy. This is illustrated in Chitwan by people leaving small gifts (e.g., fruit) at animal altars, often symbolizing elephants and tigers, to help ensure safe passage through the forests. Local knowledge and perceptions of wildlife in turn influence how people interact with wildlife and view their conservation (Kissui 2008). More than $90 \%$ 
of respondents to a recent survey in Chitwan acknowledged that tigers were there before people and have the right to live alongside people (Carter et al. 2012a).

Pandas and tigers also increasingly provide economic benefits to local residents through tourism. In Wolong, household average net benefits from panda-related tourism increased from $0.07 \%$ of annual income in 1998 to $6 \%$ in 2007 (Yang et al. 2013a). Local residents near Chitwan also receive direct and indirect benefits from tiger-related tourism (Bookbinder et al. 1998). However, in both sites, the benefits are not evenly distributed among local residents, with some groups (e.g., those living closer to tourist centers) benefitting disproportionately (He et al. 2008, Spiteri and Nepal 2008, Liu et al. 2012). It appears that progress is being made in ensuring that wildlife-related tourism benefits accrue to a greater number of people in both sites. In addition to providing direct economic benefits, tigers regulate ungulate populations (Terborgh et al. 1999) that, if unchecked, may devastate crop fields and reduce the availability of flora important to local residents (Ripple et al. 2014). Nonetheless, according to a recent survey, a majority of local respondents in Chitwan did not strongly associate tigers with ecological benefits (Carter et al. 2012a).

Despite the benefits wildlife confer on local residents, like those in Wolong and Chitwan, economic and psychological costs, among others, of living near wildlife are many (Inskip and Zimmermann 2009, Carter et al. 2014). Those closest to panda and tiger habitat, in particular, have incurred high costs from conservation efforts (Nepal and Weber 1995a, He et al. 2008). These costs include restrictions on certain agricultural activities, fuelwood collection, timber harvesting, and hunting. Direct negative impacts of large predators such as tigers on people are especially severe. Nearly one-half of the respondents in one study in Chitwan experienced livestock predation, with tigers often blamed for the attacks (Spiteri and Nepal 2008). Tiger attacks on people in Chitwan are occurring with increasing frequency: 65 local residents were killed between 1998 and 2006 compared to 6 during 1989-1997 (Gurung et al. 2008). The benefits and rightto-exist values that local people attribute to tigers have been moderated by these impacts, as evidenced by $40 \%$ of respondents in one study indicating that tigers were a significant nuisance (Carter et al. 2012a). Intolerance of these impacts can lead people to kill wildlife in retaliation or demand that conservation authorities control the perceived culprit animals. Twenty-five tigers thought to have attacked or threatened local residents were killed or removed from Chitwan from 1979 to 2006 (Gurung et al. 2008).

Given the diverse and changing ways in which people interact with pandas and tigers, the extent to which increases in the populations of these species provide benefits to local residents relative to costs imposed is difficult, if not impossible, to quantify. However, it is worth noting that a wide and growing array of interventions exists to reduce costs associated with the conservation of these species (e.g., ecotourism benefits, payments to offset livestock loss; Treves et al. 2006, Dickman et al. 2011).

\section{Human impacts on wildlife}

Hunting of pandas and tigers in both sites was more common in the past than now. Although most local residents would not likely be comfortable intentionally killing a panda, some local residents hunted pandas for marketable pelts. Pandas were also accidentally snared in traps for other species such as musk deer (Schaller et al. 1985). Much of the tiger hunting in Chitwan was undertaken by people from outside Chitwan. For example, two single hunting events in Chitwan, organized for the ruling elite in 1935-1936 and in 1939, culminated in the taking of 77 and 120 tigers, respectively, within the same area (Smythies 1942, Sunquist et al. 1999). Policies enacted in the second half of the 20th century in Nepal and China specifically prohibited the hunting of tigers and pandas in any area, and more broadly forbade all hunting inside national parks and nature reserves (Schaller et al. 1985, Heinen and Kattel 1992). Despite these regulations, hunting of pandas in Wolong continued throughout the 1970s and 1980s, apparently stimulated by international demand for panda pelts in wealthy nations like Japan (Schaller 1993). As many as 400 pandas were poached in the late 1970s and 1980s across the giant panda's geographic range (Hu 1989), incidents that occurred even within nature reserves, including Wolong. Hunting of tigers and their prey in Chitwan continues to be a threat (Chapron et al. 2008). However, the restrictions on hunting in Chitwan and Wolong are currently more strictly enforced than in the past (e.g., with capital punishment applied in some instances in China). Anti-poaching initiatives led by local residents have also enhanced enforcement. As a result, hunting impacts on tigers and pandas currently appear to be small in the two sites (Reid and Jien 1999, Nowell 2012).

Although hunting pressure is currently low, the habitat preferences of both tigers and pandas put them at odds with nearby human communities. The human-wildlife resource conflicts occurring in the two coupled systems mirror those occurring in other similarly diverse regions such as Russia, Bhutan, and South Africa (Ervin 2003). Many household activities in both sites, such as conversion of forest to cropland, collection of forest products (a significant component of local livelihoods), or grazing of livestock in forests, negatively affect not only the habitat of pandas and tigers but also modify their behavioral patterns (e.g., dispersal, mating). In the forests of Wolong, collection of bamboo shoots and cutting of trees (which provide cover for shade-dependent bamboo species) for timber or fuelwood fragment and otherwise degrade panda habitat (Liu et al. 2001, Viña et al. 2007). Fuelwood is one of the most important forest products in Wolong, calculated recently to constitute approximately one-half of the energy used for heating during winter and one-third of that used to cook food (it is also used to cook pig fodder; Viña et al. 2007). Similarly, in Chitwan, the collection of natural resources degrades tiger habitat, for example, by potentially decreasing grassland area in the park (Carter et al. 2013).

Livestock grazing in, and the collection of fodder from, the forests of Wolong and Chitwan also can negatively affect wildlife and their habitats in both sites (Hull et al. 2011b, 2014, Carter et al. 2013). In Wolong, free-ranging livestock, especially horses, degrade panda habitat by eating bamboo, and their very presence excludes pandas from suitable areas (Hull et al. 2014). The significant impacts of livestock on wildlife numbers, behaviors, and habitats have been noted in other regions of the world, including India, Kenya, and the United States (Madhusudan 2004, Beck and Peek 2005, Young et al. 2005). Human presence inside Chitwan's forests also disrupts the daily activity patterns of tigers. A recent study indicates that tigers overlap spatially with humans (e.g., people on foot, vehicles) in Chitwan's forests, but 
have become significantly less active during the day, when human activity peaks, to avoid humans (Carter et al. 2012b). Similar patterns have been noted elsewhere (Tigas et al. 2002, Boydston et al. 2003), for example, in Botswana, where African lions (Panthera leo) avoid temporal overlap with people when people are most active (Valeix et al. 2012).

In both sites, human impacts (e.g., resource collection, livestock husbandry) on natural systems are significantly linked with increases in household numbers. Household proliferation is a worldwide phenomenon, and because the increase in household numbers is related to decreasing household size (i.e., number of people living in the house), the per capita consumption of natural resources to maintain the household and support its occupants increases as well (Liu et al. 2003b). The growth in the number of households in Wolong and Chitwan has outstripped population growth over the last few decades (Liu et al. 1999c, Sichuan Statistics Bureau 2008, Nepal Central Bureau of Statistics 2014). It is not surprising that the area of suitable panda habitat inside Wolong Nature Reserve declined between 1974 and 1997 (Liu et al. 2001, Viña et al. 2007), and the area of highly suitable tiger habitat declined along the northern portion of Chitwan National Park between 1989 and 2009 (Carter et al. 2013).

In addition to the number of households, their spatial distribution influences the degree of their habitat impacts (Peterson et al. 2013). Past research indicates that household location has a nonlinear impact on habitat in Wolong and Chitwan. In both sites, local people are traveling farther from their home to collect natural resources than in the past, and thus, human-induced changes in wildlife habitat are occurring deeper inside both of the protected areas over time (He et al. 2009, Carter et al. 2013; Fig. $3 \mathrm{~A}, \mathrm{~B})$. Other studies in the states of Idaho, Wyoming, and Colorado, USA, also indicate that household location choices have important implications on wildlife and their conservation (Theobald et al. 1997, Peterson et al. 2008). The spatial relationships between household location and wildlife habitat are highly salient to the management of protected areas because these areas may attract human settlement (Wittemyer et al. 2008, but see Hoffman et al. 2011).

The consumption of forest products also varies with household demographic characteristics and ethnic background. For instance, fertility and marriage timing are key drivers of household formation and thus influence habitat transformation in both sites (An and Liu 2010, Axinn and Ghimire 2011). In Chitwan, forest resource use has also been found to be significantly associated with ethnicity. Lower caste Hindus and Terai Tibeto-Burmese ethnic groups, typically considered to be politically and economically marginalized groups, depend more on fuelwood than do higher caste Hindus and Hill TibetoBurmese, who appear to have greater access to alternative fuel sources such as electricity (Link et al. 2012).

\section{Disturbance}

Disturbance can be both natural (e.g., floods, fires, earthquakes) and anthropogenic (e.g., civil wars, introduction of invasive species). Such disturbance influences both natural and human subsystems and their interactions. In Chitwan, for example, largescale shifts of the Rapti River inundate some areas, whereas other areas abandoned by the river are rapidly colonized by grasses (Peet et al. 1999), which are an important food source for species that tigers consume. The environmental impacts of a major flood (i.e., inundation of cropland) in 1993 triggered the relocation of families living inside the park to an area outside (Dhakal et al. 2011). The resettled community relies mainly on natural resources from outside rather than inside the park, which they previously depended upon almost entirely (Stræde and Treue 2006).

Also, in Chitwan, local residents often set fire to grasslands to burn the leaves off the reeds, which are then used as construction materials. Fire is also viewed as a way to delay the succession of grasslands. In Wolong, fire was widely used to maintain livestock pastures in the past. However, prescribed fire was restricted in the 1970 s to protect tree plantations installed in community pastures. Now that fire is more rare, shrub encroachment in pastures is generating increased resource conflicts over grazing rights and is likely inducing some residents to graze their livestock in the forests (i.e., panda habitat).

Fig. 3. (A) Change in Bengal tiger estimated habitat suitability index (HSI) in the 1990s and 2000s with distance from human settled areas inside the northern portion of Chitwan National Park, Nepal. Source: adapted from Carter et al. (2013b). (B) Temporal dynamics of distances of fuelwood collection sites from household locations. Bars indicate mean and SE. ED, Euclidean distance between a household and its fuelwood collection site; TD, length of the shortest road traveled by a household to the corresponding fuelwood site in road networks; ND, Euclidean distance from a fuelwood collection site to the location of the nearest household. Source: adapted from He et al. 2009.

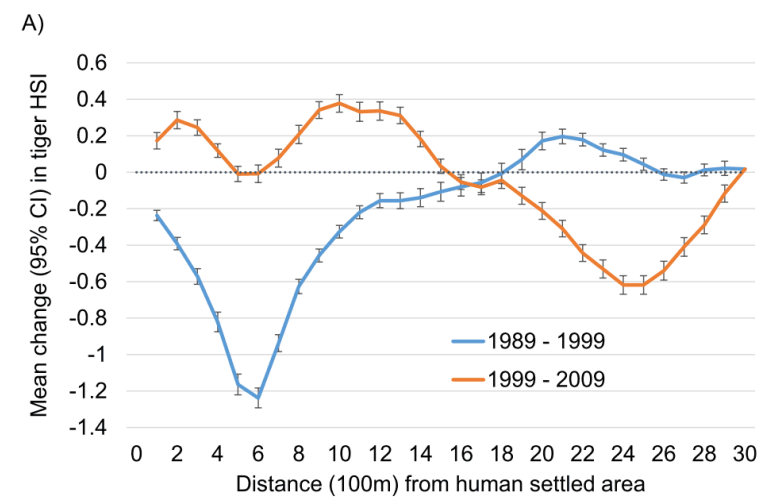

B)

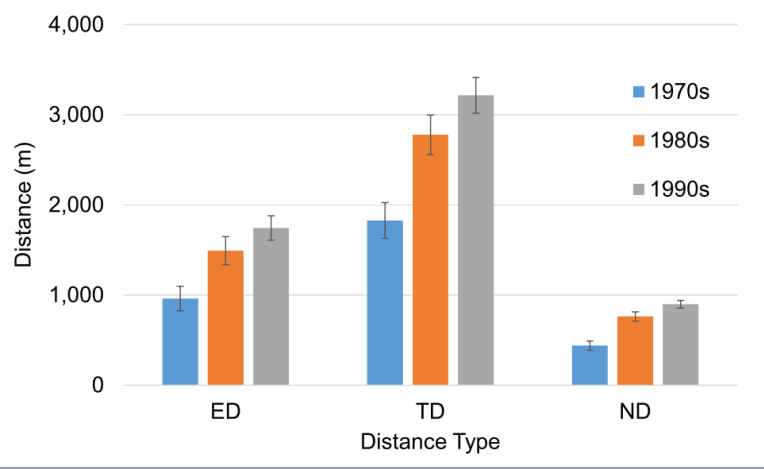


A strong earthquake in Wolong in 2008 caused a number of severe landslides that reduced forest cover (Viña et al. 2011). The earthquake also destroyed many homes, forcing people to relocate to other areas inside and outside of the reserve. However, the relocation of displaced people to consolidated residential areas with electrical cooking and heating might ultimately reduce their per capita impact on local panda habitat by reducing their reliance on fuelwood as their main fuel source (Viña et al. 2011) and increasing the abandonment of marginal agricultural fields.

Exotic and sometimes invasive organisms, considered a major threat to global biodiversity (Ricciardi et al. 2000), also impact pandas and tigers and their habitats. For instance, Mikania micranthia is an invasive vine that has spread rapidly in Chitwan since it was first reported in 2000 (Sapkota 2007). M. micranthia does not appear to be palatable to wild ungulates, and by smothering vegetation, effectively reduces the food available to tiger prey species. In Wolong, fast-growing exotic tree species, including Japanese larch (Larix kaempferi), are often used for reforestation. Although reforestation efforts provide many ecosystem services (e.g., erosion control), monospecific plantations of exotic species are not typically associated with dense bamboo understories, especially when they are young, making them less suitable for pandas than natural forest types. Smaller exotic organisms, e.g., those causing disease, might pose equal or greater danger to protected wildlife. Reduced wildlife numbers due to disease outbreaks have not been reported for Wolong and Chitwan. Given the relatively small wildlife population sizes in both sites, researchers should be alert to wildlife disease and how spread of disease is influenced by and affects humans.

Perturbations in the human subsystems, e.g., civil wars and political upheaval, are more frequent in lesser-developed regions, where a disproportionate share of the world's biodiversity occurs (Baral and Heinen 2005), as in Chitwan and Wolong. A civil war in Nepal from 1996 to 2006 affected the daily lives of people in Chitwan in profound ways (e.g., family members or friends killed, community services frequently interrupted) but also had negative consequences on tigers in Chitwan and elsewhere in Nepal. Lax security, resulting largely from the Nepal Army leaving the National Park to fight insurgents elsewhere, and inefficient anti-poaching efforts during the civil war allowed poaching of tigers to increase sharply (Baral and Heinen 2005). Human disturbance of this sort has not taken place in Wolong for some time. However, many families report that they migrated to Wolong during periods of armed conflict or social upheaval, such as during China's civil wars (1927-1935 and 1946-1950) and the Great Leap Forward (1958-1961). In addition to causing dramatic shifts in family structure and community organizations, these conflicts are also associated with significant forest loss, particularly in Sichuan province where Wolong is located (Studley 1999, Sayer and Sun 2003, Wenguang et al. 2008), and almost certainly reduced panda habitat, not only in Wolong, but also across the entire geographic range of the species.

\section{Conservation policies}

Conservation policies are implemented by human communities and are usually aimed at reducing, or reversing, human impacts on natural subsystems, and in turn have cascading effects on human-nature interactions. A rapid decline in forest cover in Chitwan district and in the population of several wildlife species (e.g., one-horned rhinoceros [Rhinoceros unicornis] and Bengal tigers) following the influx of mid-hill migrants beginning in the 1950s (Jha et al. 1994) prompted the government of Nepal to establish the country's first national park in Chitwan in 1973 (originally 54,400 ha and enlarged to 93,200 ha in 1977; Adhikari 2002). In Wolong, hunting pressure on pandas and large-scale logging in the 1960s (Schaller et al. 1985) motivated the government of China to establish the Wolong Nature Reserve in 1963 (expanded to 200,000 ha in 1975; Liu et al. 1999b, Wolong Administration Bureau 2004). Management of both protected areas emphasizes the protection of their charismatic, large-bodied wildlife species, in part, because it is viewed that their protection confers protection to a large number of co-occurring species (i. e., umbrella effect; Roberge and Angelstam 2004).

\section{Restricting land use}

Conservation measures implemented in both sites were initially based on a rather traditional strict zoning approach that involves assigning land-use rights to discrete areas to contain human impacts. In Chitwan National Park, various activities such as hunting, land clearing, and grazing livestock inside the park were prohibited (Heinen and Kattel 1992). The exclusion policies, enforced by the Nepal Army, created resentment among local residents who felt that access to forest products they relied on was denied without their consent (Nepal and Weber 1995b). To reduce park-people conflicts, a grass-cutting program was initiated in 1976 to allow local residents to enter the park for approximately two weeks annually to collect thatch grass, reeds, rope bark, and rope grass, but not wood (Stræde and Helles 2000). The grasscutting concession undoubtedly reduced local resentment toward the park; however, the program only marginally satisfies local demand for natural resources from inside the park (Nepal and Weber 1995a, Stræde and Treue 2006).

Like all other nature reserves in China, Wolong was divided into core, buffer, and experimental zones (Hull et al. 2011b). Human habitation and land uses are limited to the experimental zone, and biodiversity conservation is given priority in the core zones, with the buffer zones serving to soften the human impacts in the areas between the two. However, the effectiveness of this zoning scheme is limited by unclear policies on the requirements for each zone, poor design (e.g., zones not accurately reflecting panda habitat quality), and inability to enforce the zoning designations on the ground to contain human impacts effectively. For example, although the zoning scheme in Wolong may have succeeded in preventing the construction of houses and roads in the core zone, it proved less effective at eliminating more ephemeral activities such as livestock grazing and collection of forest products in such sensitive areas (Liu et al. 2003a, Hull et al. 2011b).

Incentive-based and collaborative approaches Following trends toward more collaborative management approaches in and around protected areas around the world (Agrawal et al. 2008), the authorities in both Chitwan and Wolong have begun to engage local residents in conservation, and these approaches appear to be more successful than top-down approaches. To combat forest degradation outside Chitwan National Park, the government of Nepal established a buffer zone 
$\left(\sim 750 \mathrm{~km}^{2}\right)$ around the park in 1996 that was designed to restore ecosystem integrity and simultaneously improve human livelihoods. Livestock grazing was prohibited in the forests of the buffer zone (Sharma 1990, Gurung et al. 2008). To offset this imposition, $30-50 \%$ of the park's annual revenue must be invested in the surrounding buffer zone to support community development programs, including alternative income opportunities and infrastructure improvement (Government of Nepal 1993). Likewise, management responsibility for several forest tracts in Chitwan's buffer zone was devolved to local community user groups (Nagendra et al. 2005, Gurung et al. 2008). Decisions on when and how natural resources can be collected from those community forests now reside with local residents according to State-sanctioned management plans (Nagendra et al. 2005). Community forestry in concert with the prohibition of livestock grazing has helped to reverse forest degradation and fragmentation in the buffer zone forests (Nagendra et al. 2008). Consequently, the buffer zone forests now support greater densities of wild tiger prey species and provide better cover for tigers (Carter et al. 2013).

The forest management policies affecting panda habitat in Wolong are perhaps broader in scope than those affecting tiger habitat in Chitwan, yet they also demonstrate the utility of involving local residents in conservation. In Wolong, the nationwide Natural Forest Conservation Program (NFCP) was implemented in a collaborative way. Initiated in 2001, NFCP aims to protect and restore natural forests through such means as logging bans, which require monitoring. Program funds were used to provide cash for residents to monitor forests collectively to prevent illegal harvesting (Liu et al. 2008, Yang et al. 2013b). Thus, in Wolong, NFCP departs from the traditional top-down model because it does not rely solely on State agents to monitor all forests. To complement NFCP, the Grain-to-Green program (GTGP), initiated in China in 2000, aims to return steep hillside cropland to forest (Liu et al. 2008). To encourage participation in the program, the Chinese government provides agricultural households with an annual payment for converting cropland to forest and keeping the converted plots forested. The implementation of both NFCP and GTGP has helped reverse a $>30$-yr trend of forest degradation in the reserve (Xu et al. 2006, Viña et al. 2007).

Experience at both sites demonstrates that the effectiveness of conservation programs such as logging bans or community forestry may be improved by leveraging social norms (Kinzig et al. 2013). In Wolong, local residents' intentions to re-enroll in the GTGP are influenced by whether or not their neighbors re-enroll (Chen et al. 2009). In Chitwan, many local residents depend on forest products; thus, despite socioeconomic and ethnic heterogeneity, prevailing norms coalesce around the sustainable collection and use of natural resources from community forests. The direct role of social norms in fostering wildlife conservation has also been documented elsewhere such as for tenrecs (Tenrec ecudatus) and pandans (Pandanus spp.) in Madagascar and lions in Kenya (Jones et al. 2008, Hazzah et al. 2014).

\section{Feedbacks}

A hallmark of the CHANS approach is its direct analysis of the reciprocal interactions of people and nature. As such, the effects of human activities on wildlife and their habitats often generate feedbacks affecting humans and their activities (Liu et al. 2007b). For example, as forest cover decreased in both sites, forests became more distant from households, which made the extraction of timber and nontimber forest products more difficult and time consuming (He et al. 2009, Axinn and Ghimire 2011). Such changes reciprocally influence human demographic behavior, including childbearing, which in turn affect wildlife habitat. For example, in Chitwan, increasing costs and time in collecting forest products are linked to population growth because couples bear more children to help support the household and collect forest resources (Biddlecom et al. 2005).

Conservation policies are important feedbacks in coupled systems. As noted, pervasive ecological degradation in both sites triggered initial conservation policies (e.g., establishment of protected areas) to mitigate, or even reverse, human impacts on the natural subsystem. The limited success of the initial conservation approach (strict zones with insufficient resources for enforcement), created a further feedback in which conservation agencies in both sites pursued more collaborative approaches to forest governance.

As the positive effects of habitat conservation policies in both sites become manifest, feedbacks are also emerging in the form of human-wildlife conflicts. For example, increased forest cover in Wolong appears to be resulting in an increase in the population of native wildlife species that are raiding cropland and tree seedlings (Fleischner 1994, Liu et al. 1999a, Ran 2003, State Forestry Administration 2006, Steinfeld et al. 2006). In Chitwan, forest recovery is attracting and supporting greater numbers of tigers (Barlow et al. 2009), resulting in an increase in the number of attacks on people over the last 15 years (Gurung et al. 2008). The feedback of wildlife recovery on human livelihoods has occurred in many places, for example, in the United States and Europe, where increasing reports of livestock predation have been correlated with the recovery of wolves (Skogen et al. 2008).

Forest conservation policies in both sites have given rise to other types of feedback. Perhaps as a means of filling the income gap created by the loss of pasture and the timber harvesting ban in China (i.e., NFCP), local residents in Wolong began commercial horse breeding and keeping their horses in the forest to take advantage of the lack of natural livestock predators and lax enforcement of grazing restrictions (Hull et al. 2011b). Recently, however, such free grazing became severe enough to warrant more strict enforcement by the reserve administration, and residents have been forced to sell their herds (V. Hull and J. Liu, personal observation). In contrast to Wolong, grazing restrictions in Chitwan are more strictly enforced through monitoring and sanctions, although some illegal grazing still occurs. In response to these restrictions, households in Chitwan have reduced the number of free-ranging livestock (e.g., buffalo) and have increased livestock stall feeding. Currently, people prefer goats because they are easier to stall feed and because goat milk and meat is commercially valuable. The costs of keeping larger livestock are high, and livestock are now less commonly used as draft animals due to the adoption of mechanized farm equipment and declining agricultural land holdings (Gurung et al. 2009).

\section{TELECOUPLING PROCESSES}

People in both sites have always been connected to distant places, as evidenced by historical records of migration and trade routes. 
However, the vast and rapid expansion of transportation and communication technologies in the past century has increasingly connected both sites to previously distant places through the transport of goods, people, and information. These flows constitute telecoupling processes when they influence both socioeconomic and environmental interactions among CHANS (see Liu et al. 2013 for discussion of the telecoupling framework). Telecoupling links coupled systems to other distant coupled systems to form complex interactive systems; for example, many residents from Chitwan work as migrant laborers in the Middle East.

Conservation policies implemented in both sites are examples of telecouplings. The policy frameworks used to set aside areas of Chitwan and Wolong as protected areas were developed primarily by the central governments in Kathmandu and Beijing (i.e., coupled systems distant from the focal sites), both of which were eager to join the community of nations seeking to preserve the Earth's dwindling biodiversity. Because we have already explored several socioeconomic and environmental implications of different conservation policies in both sites (as well as their feedbacks), we next focus on two other telecoupling processes (while acknowledging that many others also exist) that have cascading and important effects on pandas and tigers as well as humans: migration and tourism.

\section{Migration}

Earlier, we mentioned human immigration in both sites. Here, we focus on rural-urban migration, a long-standing feature of the process of industrialization (Montgomery 2008). Rising aspiration fueled by access to a range of media portraying urban lifestyles and the lure of employment in urban areas (e.g., Chengdu and Beijing in China; Kathmandu in Nepal), where higher-paying jobs are more prevalent, has spurred out-migration from both sites. Out-migration has influenced household demographics and the economy of both sites. For example, those migrating from Wolong and Chitwan are mostly men, leaving the women to maintain the households and collect forest resources (Bohra and Massey 2009, Chen et al. 2012a). Additionally, an increasing proportion of household income comes from remittances sent from family members working in areas outside Wolong and Chitwan (Bohra and Massey 2009, Chen et al. 2012a). Out-migration consequently has significant implications for wildlife habitat dynamics. One study predicts that the relocation of people between 17 and 25 years old from Wolong will substantially aid the recovery of panda habitat in the future (Liu et al. 1999b). Also, household goods and services (e.g., electricity) purchased with remittances may substitute for local natural resources (e.g., fuelwood) and reduce human pressure on nearby wildlife habitat in both sites (Chen et al. 2012a, Bhandari 2013, Bohra-Mishra 2013).

It is important to note that changes in these two coupled systems caused by telecoupling processes have spillover effects on other coupled systems (Liu et al. 2013). Although electricity, stall feeding of livestock, mechanization of farm equipment, and rural-urban migration may benefit tigers and pandas in Chitwan and Wolong, their socioeconomic and environmental impacts outside these coupled systems may be severe and broader in scale. For example, much of the electricity in Wolong and Chitwan is generated by hydroelectric power plants straddling the rivers within and near the protected areas. So while greater dependence on electricity may reduce natural resource demands by local people from within panda and tiger habitat, landslides, water and air pollution, greenhouse gas emissions, soil erosion, and biodiversity losses associated with electricity generation could offset these gains. Other questions remain, such as how does mechanization influence local and regional pollution or demand for fuel, and does the food used for stall feeding livestock negatively affect the food security or agricultural output of places outside Wolong and Chitwan? We add our voice to recent calls (Liu and Yang 2013, Liu et al. 2013) for more systematic assessments of these spillover systems under the telecoupling framework and explicit consideration of them when developing and implementing policies.

\section{Tourism}

Although rural-urban migration may help to reduce local consumption of natural resources (Chen et al. 2012a), the booming tourism industry at both sites appears to have ambiguous effects (He et al. 2008, Liu et al. 2012). Corresponding with worldwide trends (Balmford et al. 2009), Wolong and Chitwan have been visited by a growing number of domestic and international tourists over the past two decades. The number of tourists visiting Wolong increased 10-fold between $1996(\sim 20,000)$ and 2006 ( 200,000; Liu et al. 2012). In Chitwan, tourist numbers more than tripled between $1990(36,500)$ and $2009(113,788$; Bookbinder et al. 1998, Government of Nepal 2009). Accordingly, employment of local people in the tourism industry (e.g., nature guides, hotel support staff) has increased. Furthermore, new tourism infrastructure (e.g., roads, lodges) are leading Wolong and Chitwan's residents increasingly to find employment in the construction sector (Axinn and Ghimire 2011, Liu et al. 2012).

On the one hand, many conservation strategies envision tourism as an ideal means to support or supplement local livelihoods and thus reduce local demand for forest resources (Bookbinder et al. 1998, Liu et al. 2012). On the other hand, factors associated with increasing tourism (e.g., greater infrastructure development, new markets for local residents, and increased human presence) might detrimentally affect wildlife habitat and behavior. For instance, growth of the tourism industry after Wolong Nature Reserve was established led local people to use more fuelwood to produce marketable goods (e.g., smoked pork), thus exacerbating panda habitat degradation (Liu et al. 2001). In Chitwan, no lodges existed outside the National Park in 1977, but 60 were in operation by 1998, giving rise to concerns that unregulated growth in tourism would disturb wildlife and their habitats inside the park (UNESCO/IUCN 2003).

\section{CONCLUSIONS}

Our cross-site synthesis of CHANS dynamics in Wolong and Chitwan indicates that many factors in the human subsystem, including community (e.g., organizations and services) and local resident characteristics (e.g., socioeconomics and demography), affect wildlife and their habitats, and vice versa. These interactions are further complicated by human and natural disturbance, feedbacks (including policies), and telecouplings that link the focal systems with other distant systems (see Figs. 4 and 5 for examples of the general CHANS framework applied to Wolong and Chitwan, respectively). For example, the CHANS approach 
Fig. 4. Illustration of relationships within the human and natural subsystems as well as human-nature interactions that are important to understanding and conserving giant pandas in Wolong Nature Reserve, China. Relations are shown using a general coupled human and natural systems (CHANS) framework (see Fig. 1), and are not exhaustive or constant over time and across space. We encourage future research and conservation efforts to use this CHANS approach to continue filling in important information gaps in this and other sites where people and wildlife interact in complex ways.

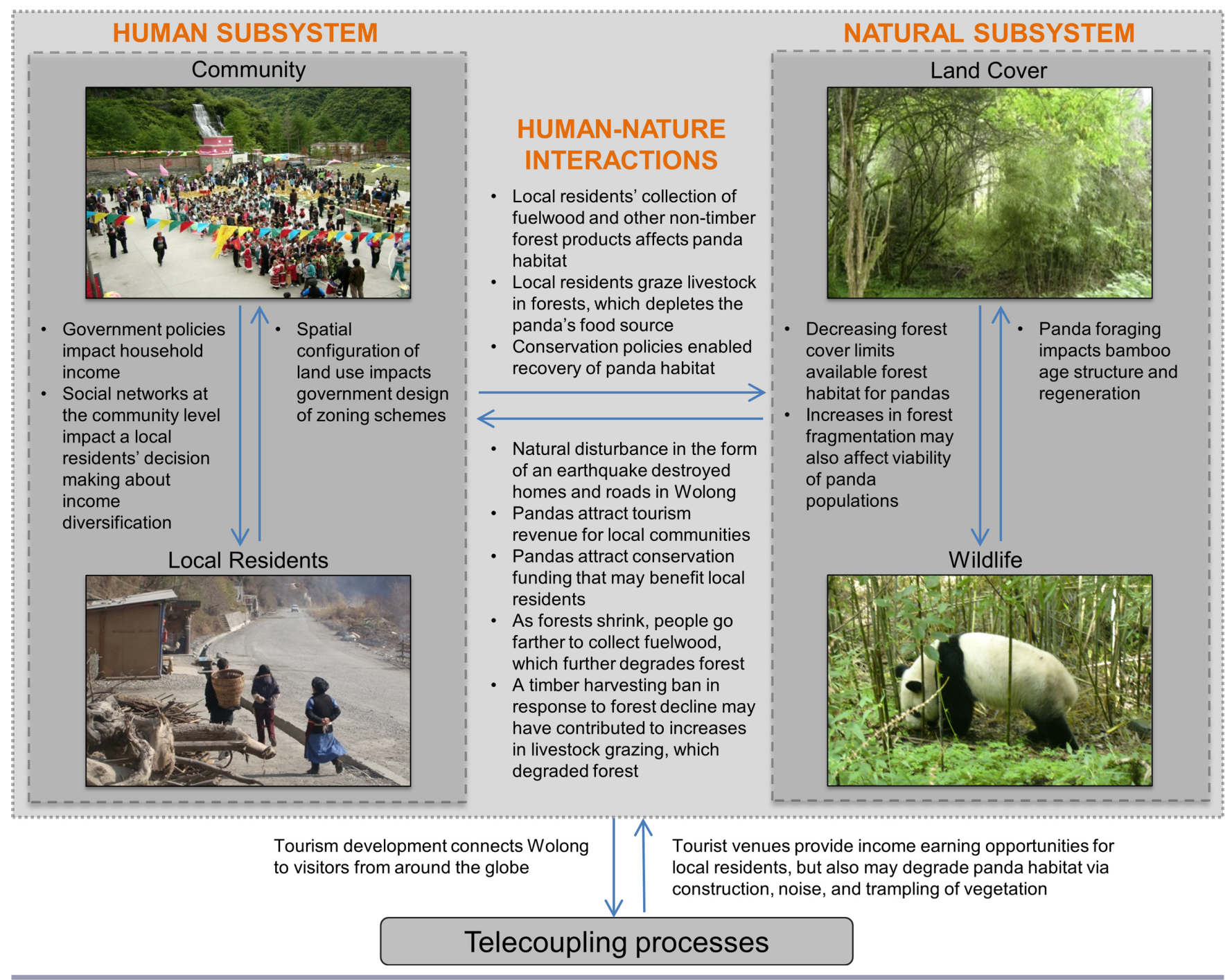

reveals some key within-household dynamics (e.g., fertility and marriage timing) underlying important aggregate-level patterns (e.g., household number associated with habitat loss). The CHANS approach also reveals the normative basis of a farmer's decision to participate in conservation activities or engage in particular resource consumption behaviors. These connections, so important for developing effective conservation plans, would likely have been missed had an integrated CHANS research approach not been used. Moreover, we argue that a CHANS approach can fill many remaining information gaps crucial to conserving wildlife in human-influenced areas.
The many links between local human communities and wildlife demonstrated in this synthesis further strengthen the rationale for the collaboration of environmental and social scientists when conducting CHANS research and developing policy recommendations (Roy et al. 2013). Conducting long-term studies is especially important because it allows an interdisciplinary team of researchers to witness and understand feedbacks as well as telecoupling (McConnell et al. 2011, Hummel et al. 2012, Liu 2014). Furthermore, incorporating ideas, concepts, and methods from a wide and broadening range of disciplines into long-term research projects will foster theoretical development and generate innovative and actionable solutions (Palmer 2012) for reconciling 
Fig. 5. Illustration of relationships within the human and natural subsystems as well as human-nature interactions that are important to understanding and conserving Bengal tigers in Chitwan National Park, Nepal. Relations are shown using a general coupled human and natural systems (CHANS) framework (see Fig. 1), and are not exhaustive or constant over time and across space. We encourage future research and conservation efforts to use this CHANS approach to continue filling in important information gaps in this and other sites where people and wildlife interact in complex ways.

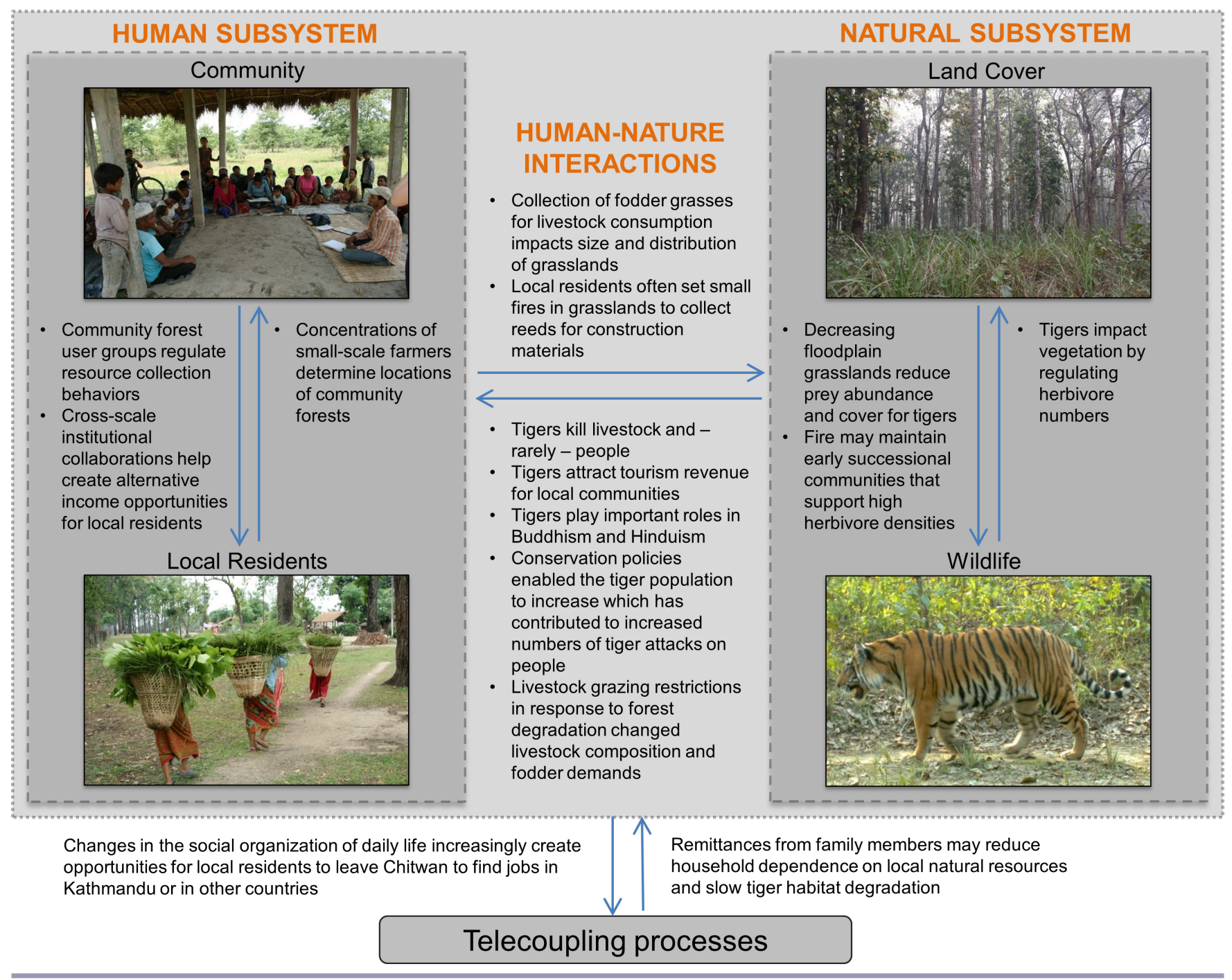

the needs of a growing human population with the desire to protect wildlife in an increasingly interconnected world.

Responses to this article can be read online at:

http://www.ecologyandsociety.org/issues/responses. $\mathrm{php} / 6881$

\section{Acknowledgments:}

We thank the International Trust for Nature Conservation (UK), Tiger Tops Jungle Lodge, the Institute for Social and Environmental Research-Nepal, Wolong Nature Reserve, and the Chinese Academy of Sciences for their contributions to the research underlying this paper, as well as the Nepal Department of National Parks and Wildlife Conservation, the State Forestry Administration, and the Sichuan Forestry Department for permission to collect data inside Chitwan National Park and Wolong Nature Reserve. The United States Fish and Wildlife Service Rhinoceros and Tiger Conservation Fund, the National Science Foundation (Partnerships in International Research and Education, Dynamics of Coupled Natural and Human Systems Program), Michigan State University AgBioResearch, and National Aeronautics and Space Administration provided funding for the research that was the foundation of this paper. We thank numerous collaborators and former students and postdoctoral associates associated with previous work in Wolong and Chitwan, as well as two anonymous reviewers and the subject editor for helpful comments on earlier drafts of this manuscript. 


\section{LITERATURE CITED}

Adhikari, T. R. 2002. The curse of success. Habitat Himalaya 9 (3). [online] URL: http://sosrhino.org/news/Updatepoaching. pdf.

Agrawal, A., A. Chhatre, and R. Hardin. 2008. Changing governance of the world's forests. Science 320:1460-1462. http:// dx.doi.org/10.1126/science.1155369

Agrawal, A., and E. Ostrom. 2001. Collective action, property rights, and decentralization in resource use in India and Nepal. Politics and Society 29(4):485-514. http://dx.doi. org/10.1177/0032329201029004002

An, L., and J. Liu. 2010. Long-term effects of family planning and other determinants of fertility on population and environment: agent-based modeling evidence from Wolong Nature Reserve, China. Population and Environment 31 (6):427-459. http://dx.doi.org/10.1007/s11111-010-0111-3

An, L., J. Liu, Z. Ouyang, M. Linderman, S. Zhou, and H. Zhang. 2001. Simulating demographic and socioeconomic processes on household level and implications for giant panda habitats. Ecological Modelling 140(1-2):31-49. http://dx.doi.org/10.1016/ $\underline{\text { S0304-3800(01)00267-8 }}$

Axinn, W. G., and D. J. Ghimire. 2011. Social organization, population, and land use. American Journal of Sociology 117 (1):209-258. http://dx.doi.org/10.1086/661072

Balmford, A., J. Beresford, J. Green, R. Naidoo, M. Walpole, and A. Manica. 2009. A global perspective on trends in nature-based tourism. PLoS Biology 7: e1000144. http://dx.doi.org/10.1371/ journal.pbio. 1000144

Baral, N., and J. T. Heinen. 2005. The Maoist people's war and conservation in Nepal. Politics and the Life Sciences 24(1-2):2-11. http://dx.doi.org/10.2990/1471-5457(2005)24[2:TMPWAC]2.0.CO;2

Barlow, A. C. D., C. McDougal, J. L. D. Smith, B. Gurung, S. R. Bhatta, S. Kumal, B. Mahato, and D. B. Tamang. 2009. Temporal variation in tiger (Panthera tigris) populations and its implications for monitoring. Journal of Mammalogy 90(2):472-478. http://dx. doi.org/10.1644/07-MAMM-A-415.1

Bearer, S., M. Linderman, J. Huang, L. An, G. He, and J. Liu. 2008. Effects of fuelwood collection and timber harvesting on giant panda habitat use. Biological Conservation 141(2):385-393. http://dx.doi.org/10.1016/j.biocon.2007.10.009

Beck, J. L., and J. M. Peek. 2005. Diet composition, forage selection, and potential for forage competition among elk, deer, and livestock on aspen-sagebrush summer range. Rangeland Ecology and Management 58(2):135-147. http://dx.doi.org/10.2111/03-13.1

Bertzky, B., C. Corrigan, J. Kemsey, S. Kenney, C. Ravilious, C. Besançon, and N. Burgess. 2012. Protected planet report 2012: tracking progress towards global targets for protected areas. IUCN, Gland, Switzerland, and UNEP-WCMC, Cambridge, UK. [online] URL: http://cmsdata.iucn.org/downloads/ protected planet report.pdf.

Bhandari, P. B. 2013. Rural livelihood change? Household capital, community resources and livelihood transition. Journal of Rural Studies 32:126-136. http://dx.doi.org/10.1016/j.jrurstud.2013.05.001
Biddlecom, A. E., W. G. Axinn, and J. S. Barber. 2005. Environmental effects on family size preferences and subsequent reproductive behavior in Nepal. Population and Environment 26 (3):583-621. http://dx.doi.org/10.1007/s11111-005-1874-9

Bohra, P., and D. S. Massey. 2009. Processes of internal and international migration from Chitwan, Nepal. International Migration Review 43(3):621-651. http://dx.doi.org/10.1111/ j.1747-7379.2009.00779.x

Bohra-Mishra, P. 2013. Labour migration and investments by remaining households in rural Nepal. Journal of Population Research 30(2):171-192. http://dx.doi.org/10.1007/s12546-012-9097-2

Bookbinder, M. P., E. Dinerstein, A. Rijal, H. Cauley, and A. Rajouria. 1998. Ecotourism's support of biodiversity conservation. Conservation Biology 12(6):1399-1404. http://dx. doi.org/10.1111/j.1523-1739.1998.97229.X

Boydston, E. E., K. M. Kapheim, H. E. Watts, M. Szykman, and K. E. Holekamp. 2003. Altered behaviour in spotted hyenas associated with increased human activity. Animal Conservation 6 (3):207-219. http://dx.doi.org/10.1017/S1367943003003263

Carter, N. H., B. Gurung, A. Viña, H. Campa III, J. B. Karki, and J. Liu. 2013. Assessing spatiotemporal changes in tiger habitat across different land management regimes. Ecosphere 4: art124. http://dx.doi.org/10.1890/ES13-00191.1

Carter, N. H., S. J. Riley, and J. Liu. 2012a. Utility of a psychological framework for carnivore conservation. Oryx 46 (4):525-535. http://dx.doi.org/10.1017/S0030605312000245

Carter, N. H., S. J. Riley, A. Shortridge, B. K. Shrestha, and J. Liu. 2014. Spatial assessment of attitudes toward tigers in Nepal. Ambio 43(2):125-137. http://dx.doi.org/10.1007/s13280-013-0421-7

Carter, N. H., B. K. Shrestha, J. B. Karki, N. M. B. Pradhan, and J. Liu. 2012b. Coexistence between wildlife and humans at fine spatial scales. Proceedings of the National Academy of Sciences 109(38):15360-15365. http://dx.doi.org/10.1073/pnas. 1210490109

Chapron, G., D. G. Miquelle, A. Lambert, J. M. Goodrich, S. Legendre, and J. Clobert. 2008. The impact on tigers of poaching versus prey depletion. Journal of Applied Ecology 45 (6):1667-1674. http://dx.doi.org/10.1111/j.1365-2664.2008.01538. $\underline{\mathrm{x}}$

Chaudhary, R. P. 1998. Biodiversity in Nepal: status and conservation. Tecpress Books, Saharanpur, India.

Chen, X., K. A. Frank, T. Dietz, and J. Liu. 2012a. Weak ties, labor migration, and environmental impacts: toward a sociology of sustainability. Organization and Environment 25(1):3-24. http:// dx.doi.org/10.1177/1086026611436216

Chen, X., F. Lupi, L. An, R. Sheely, A. Viña, and J. Liu. $2012 b$. Agent-based modeling of the effects of social norms on enrollment in payments for ecosystem services. Ecological Modelling 229:16-24. http://dx.doi.org/10.1016/j.ecolmodel.2011.06.007

Chen, X., F. Lupi, G. He, and J. Liu. 2009. Linking social norms to efficient conservation investment in payments for ecosystem services. Proceedings of the National Academy of Sciences 106 (28):11812-11817. http://dx.doi.org/10.1073/pnas.0809980106 
Coleman, J. S. 1994. Foundations of social theory. Harvard University Press, Cambridge, Massachusetts, USA.

De Groot, R. S., M. A. Wilson, and R. M. J. Boumans. 2002. A typology for the classification, description and valuation of ecosystem functions, goods and services. Ecological Economics 41(3):393-408. http://dx.doi.org/10.1016/S0921-8009(02)00089-7

Descola, P., and G. Pálsson. 2013. Nature and society: anthropological perspectives. Routledge, London, UK. http://dx. doi.org/10.4324/9780203451069

Dhakal, N. P., K. C. Nelson, and J. L. D. Smith. 2011. Resident well-being in conservation resettlement: the case of Padampur in the Royal Chitwan National Park, Nepal. Society and Natural Resources 24(6):597-615. http://dx.doi.org/10.1080/08941921003709633

Dickman, A. J., E. A. Macdonald, and D. W. Macdonald. 2011. A review of financial instruments to pay for predator conservation and encourage human-carnivore coexistence. Proceedings of the National Academy of Sciences 108(34):13937-13944. http://dx. doi.org/10.1073/pnas.1012972108

Department of National Parks and Wildlife Conservation. 1999. Tiger conservation action plan for the Kingdom of Nepal. WWF Nepal Program, Kathmandu, Nepal.

Eisenberg, J. F., and J. Seidensticker. 1976. Ungulates in southern Asia: a consideration of biomass estimates for selected habitats. Biological Conservation 10(4):293-308. http://dx.doi.org/10.1016/0006-3207 (76)90003-3

Ervin, J. 2003. Rapid assessment of protected area management effectiveness in four countries. BioScience 53(9):833-841. http:// dx.doi.org/10.1641/0006-3568(2003)053[0833:RAOPAM]2.0.CO;2

Fleischner, T. L. 1994. Ecological costs of livestock grazing in western North America. Conservation Biology 8(3):629-644. http://dx.doi.org/10.1046/j.1523-1739.1994.08030629.x

Ghimire, K. B. 1997. Conservation and social development: an assessment of Wolong and other panda reserves in China. Pages 187-213 in K. B. Ghimire and M. P. Pimbert, editors. Social change and conservation: environmental politics and impacts of national parks and protected areas. Earthscan, London, UK.

Government of Nepal. 1993. Fourth amendment to the national parks and wildlife conservation act (2029). Nepal Gazette 43 (Supplement).

Government of Nepal. 2009. Nepal tourism statistics 2009 annual statistical report. Government of Nepal, Ministry of Tourism and Civil Aviation, Kathmandu, Nepal.

Granovetter, M. S. 1973. The strength of weak ties. American Journal of Sociology 78(6):1360-1380. http://dx.doi.org/10.1086/225469

Gurung, B., K. C. Nelson, and J. L. D. Smith. 2009. Impact of grazing restrictions on livestock composition and husbandry practices in Madi Valley, Chitwan National Park, Nepal. Environmental Conservation 36(4):338-347. http://dx.doi.org/10.1017/ $\underline{\mathrm{S} 0376892910000160}$

Gurung, B., J. L. D. Smith, C. McDougal, J. B. Karki, and A. Barlow. 2008. Factors associated with human-killing tigers in Chitwan National Park, Nepal. Biological Conservation 141 (12):3069-3078. http://dx.doi.org/10.1016/j.biocon.2008.09.013
Hazzah, L., S. Dolrenry, L. Naughton, C. T. T. Edwards, O. Mwebi, F. Kearney, and L. Frank. 2014. Efficacy of two lion conservation programs in Maasailand, Kenya. Conservation Biology 28(3):851-860. http://dx.doi.org/10.1111/cobi.12244

He, G., X. Chen, S. Beaer, M. Colunga, A. Mertig, L. An, S. Zhou, M. Linderman, Z. Ouyang, S. Gage, S. Li, and J. Liu. 2009. Spatial and temporal patterns of fuelwood collection in Wolong Nature Reserve: implications for panda conservation. Landscape and Urban Planning 92(1):1-9. http://dx.doi.org/10.1016/j. landurbplan.2009.01.010

He, G., X. Chen, W. Liu, S. Bearer, S. Zhou, L. Y. Cheng, H. Zhang, Z. Ouyang, and J. Liu. 2008. Distribution of economic benefits from ecotourism: a case study of Wolong Nature Reserve for Giant Pandas in China. Environmental Management 42 (6):1017-1025. http://dx.doi.org/10.1007/s00267-008-9214-3

Heinen, J. T., and B. Kattel. 1992. A review of conservation legislation in Nepal: past progress and future needs. Environmental Management 16(6):723-733. http://dx.doi.org/10.1007/ $\underline{\mathrm{BF} 02645662}$

Hoekstra, J. M., T. M. Boucher, T. H. Ricketts, and C. Roberts. 2005. Confronting a biome crisis: global disparities of habitat loss and protection. Ecology Letters 8(1):23-29. http://dx.doi. org/10.1111/j.1461-0248.2004.00686.x

Hoffman, D. M., D. Fay, and L. Joppa. 2011. Introduction: human migration to protected area edges in Africa and Latin America: questioning large-scale statistical analysis. Conservation and Society 9(1):1-7. http://dx.doi.org/10.4103/0972-4923.79177

$\mathrm{Hu}$, J. C. 1989. Life of the Giant Panda. Chongqing University Press, Chongqing, China.

Hu, J. C. 2001. Research on the Giant Panda. Shanghai Publishing House of Science and Technology, Shanghai, China.

Hull, V., A. Shortridge, B. Liu, S. Bearer, X. Zhou, J. Huang, S. Zhou, H. Zhang, Z. Ouyang, and J. Liu. 2011a. The impact of giant panda foraging on bamboo dynamics in an isolated environment. Plant Ecology 212(1):43-54. http://dx.doi. org/10.1007/s11258-010-9800-3

Hull, V., W. Xu, W. Liu, S. Zhou, A. Viña, J. Zhang, M.-N. Tuanmu, J. Huang, M. Linderman, X. Chen, Y. Huang, Z. Ouyang, H. Zhang, and J. Liu. 2011b. Evaluating the efficacy of zoning designations for protected area management. Biological Conservation 144(12):3028-3037. http://dx.doi.org/10.1016/j. biocon.2011.09.007

Hull, V., J. Zhang, S. Zhou, J. Huang, A. Viña, W. Liu, M.-N. Tuanmu, R. Li, D. Liu, W. Xu, Y. Huang, Z. Ouyang, H. Zhang, and J. Liu. 2014. Impact of livestock on giant pandas and their habitat. Journal for Nature Conservation 22(3)256-264. http://dx. doi.org/10.1016/j.jnc.2014.02.003

Hummel, D., S. Adamo, A. de Sherbinin, L. Murphy, R. Aggarwal, L. Zulu, J. Liu, and K. Knight. 2012. Inter- and transdisciplinary approaches to population-environment research for sustainability aims: a review and appraisal. Population and Environment 34(4):481-509. http://dx.doi. org/10.1007/s11111-012-0176-2 
Ingold, T. 2000. The perception of the environment: essays on livelihood, dwelling and skill. Psychology Press, London, UK. http://dx.doi.org/10.4324/9780203466025

Inskip, C., and A. Zimmermann. 2009. Human-felid conflict: a review of patterns and priorities worldwide. Oryx 43(1):18-34. http://dx.doi.org/10.1017/S003060530899030X

Jazairy, I., M. Alamgir, and T. Panuccio. 1992. The state of world rural poverty: an inquiry into its causes and consequences. New York University Press, New York, New York, USA.

Jha, P. K., G. P. S. Ghimire, and G. R. Tripathi. 1994. Royal Chitwan National Park past and present. Tiger Paper 21:5-10.

Jones, J. P. G., M. M. Andriamarovololona, and N. Hockley. 2008. The importance of taboos and social norms to conservation in Madagascar. Conservation Biology 22(4):976-986. http://dx.doi. org/10.1111/j.1523-1739.2008.00970.x

Kant, S. 2001. The evolution of forest regimes in India and China. Pages 341-351 in M. Palo, J. Uusivuori, and G. Mery, editors. World forests, markets and policies. Springer, New York, New York, USA. http://dx.doi.org/10.1007/978-94-010-0664-4 23

Karki, J. B., B. Pandav, S. R. Jnawali, R. Shrestha, N. M. B. Pradhan, B. R. Lamichane, P. Khanal, N. Subedi, and Y. V. Jhala. 2014. Estimating the abundance of Nepal's largest population of tigers Panthera tigris. Oryx, in press. http://dx.doi.org/10.1017/ $\underline{\text { S0030605313000471 }}$

Kinzig, A. P., P. R. Ehrlich, L. J. Alston, K. Arrow, S. Barrett, T. G. Buchman, G. C. Daily, B. Levin, S. Levin, M. Oppenheimer, E. Ostrom, and D. Saari. 2013. Social norms and global environmental challenges: the complex interaction of behaviors, values, and policy. BioScience 63(3):164-175. http://dx.doi. org/10.1525/bio.2013.63.3.5

Kissui, B. M. 2008. Livestock predation by lions, leopards, spotted hyenas, and their vulnerability to retaliatory killing in the Maasai steppe, Tanzania. Animal Conservation 11(5):422-432. http://dx. doi.org/10.1111/j.1469-1795.2008.00199.x

Linderman, M. A., L. An, S. Bearer, G. He, Z. Ouyang, and J. Liu. 2005a. Modeling the spatio-temporal dynamics and interactions of households, landscapes, and giant panda habitat. Ecological Modelling 183(1):47-65. http://dx.doi.org/10.1016/j. ecolmodel.2004.07.026

Linderman, M., S. Bearer, L. An, Y. Tan, Z. Ouyang, and J. Liu. $2005 b$. The effects of understory bamboo on broad-scale estimates of giant panda habitat. Biological Conservation 121 (3):383-390. http://dx.doi.org/10.1016/j.biocon.2004.05.011

Link, C. F., W. G. Axinn, and D. J. Ghimire. 2012. Household energy consumption: community context and the fuelwood transition. Social Science Research 41(3):598-611. http://dx.doi. org/10.1016/j.ssresearch.2011.12.007

Liu, F., W. J. McShea, D. L. Garshelis, X. Zhu, D. Wang, and L. Shao. 2011. Human-wildlife conflicts influence attitudes but not necessarily behaviors: factors driving the poaching of bears in China. Biological Conservation 144(1):538-547. http://dx.doi. org/10.1016/j.biocon.2010.10.009

Liu, J. 2010. China's road to sustainability. Science 328:50. http:// dx.doi.org/10.1126/science.1186234
Liu, J. 2014. Forest sustainability in China and implications for a telecoupled world. Asia and the Pacific Policy Studies 1 (1):230-250. http://dx.doi.org/10.1002/app5.17

Liu, J., L. An, S. S. Batie, R. E. Groop, Z. Liang, M. A. Linderman, A. G. Mertig, Z. Ouyang, and J. Qi. 2003a. Human impacts on land cover and panda habitat in Wolong Nature Reserve: linking ecological, socioeconomic, demographic, and behavioral data. Pages 241-263 in J. Fox, R. R. Rindfuss, S. J. Walsh, and V. Mishra, editors. People and the environment: approaches for linking household and community surveys to remote sensing and GIS. Kluwer, New York, New York, USA.

Liu, J., G. C. Daily, P. R. Ehrlich, and G. W. Luck. 2003b. Effects of household dynamics on resource consumption and biodiversity. Nature 421:530-533. http://dx.doi.org/10.1038/ nature01359

Liu, J., and J. Diamond. 2005. China's environment in a globalizing world. Nature 435:1179-1186. http://dx.doi. org/10.1038/4351179a

Liu, J., T. Dietz, S. R. Carpenter, M. Alberti, C. Folke, E. Moran, A. N. Pell, P. Deadman, T. Kratz, J. Lubchenco, E. Ostrom, Z. Ouyang, W. Provencher, C. L. Redman, S. H. Schneider, and W. W. Taylor. 2007a. Complexity of coupled human and natural systems. Science 317:1513-1516. http://dx.doi.org/10.1126/ science. 1144004

Liu, J., T. Dietz, S. R. Carpenter, C. Folke, M. Alberti, C. L. Redman, S. H. Schneider, E. Ostrom, A. N. Pell, J. Lubchenco, W. W. Taylor, Z. Ouyang, P. Deadman, T. Kratz, and W. Provencher. 2007b. Coupled human and natural systems. Ambio 36(8):639-649. http://dx.doi.org/10.1579/0044-7447(2007)36[639: CHANS]2.0.CO;2

Liu, J., V. Hull, M. Batistella, R. DeFries, T. Dietz, F. Fu, T. W. Hertel, R. C. Izaurralde, E. F. Lambin, S. Li, L. A. Martinelli, W. J. McConnell, E. F. Moran, R. Naylor, Z. Ouyang, K. R. Polenske, A. Reenberg, G. de Miranda Rocha, C. S. Simmons, P. H. Verburg, P. M. Vitousek, F. Zhang, and C. Zhu. 2013. Framing sustainability in a telecoupled world. Ecology and Society 18(2): 26. http://dx.doi.org/10.5751/ES-05873-180226

Liu, J., K. Ickes, P. S. Ashton, J. V. La Frankie, and N. Manokaran. 1999a. Spatial and temporal impacts of adjacent areas on the dynamics of species diversity in a primary forest. Pages 42-69 in D. J. Mladenoff and W. L. Baker, editors. Spatial modeling of forest landscape change: approaches and applications. Cambridge University Press, Cambridge, UK.

Liu, J., S. Li, Z. Ouyang, C. Tam, and X. Chen. 2008. Ecological and socioeconomic effects of China's policies for ecosystem services. Proceedings of the National Academy of Sciences 105 (28):9477-9482. http://dx.doi.org/10.1073/pnas.0706436105

Liu, J., M. Linderman, Z. Ouyang, L. An, J. Yang, and H. Zhang. 2001. Ecological degradation in protected areas: the case of Wolong Nature Reserve for Giant Pandas. Science 292:98-101. http://dx.doi.org/10.1126/science.1058104

Liu, J., Z. Ouyang, Y. Tan, J. Yang, and H. Zhang. 1999b. Changes in human population structure: implications for biodiversity conservation. Population and Environment 21(1):45-58. http://dx. doi.org/10.1023/A:1022101026466 
Liu, J., Z. Ouyang, W. W. Taylor, R. Groop, Y. Tan, and H. Zhang. 1999c. A framework for evaluating the effects of human factors on wildlife habitat: the case of giant pandas. Conservation Biology 13(6):1360-1370. http://dx.doi.org/10.1046/j.1523-1739.1999.98418. $\underline{x}$

Liu, J., and W. Yang. 2013. Integrated assessments of payments for ecosystem services programs. Proceedings of the National Academy of Sciences 110(41):16297-16298. http://dx.doi. org/10.1073/pnas.1316036110

Liu, W., C. A. Vogt, J. Luo, G. He, K. A. Frank, and J. Liu. 2012. Drivers and socioeconomic impacts of tourism participation in protected areas. PLoS One 7: e35420. http://dx.doi.org/10.1371/ journal.pone. 0035420

Madhusudan, M. D. 2004. Recovery of wild large herbivores following livestock decline in a tropical Indian wildlife reserve. Journal of Applied Ecology 41(5):858-869. http://dx.doi. org/10.1111/j.0021-8901.2004.00950.X

Manfredo, M. J., J. J. Vaske, P. J. Brown, D. J. Decker, and E. A. Duke, editors. 2009. Wildlife and society: the science of human dimensions. Island Press, Washington, D.C., USA.

Matthews, S. A., G. P. Shivakoti, and N. Chhetri. 2000. Population forces and environmental change: observations from western Chitwan, Nepal. Society and Natural Resources 13(8):763-775. http://dx.doi.org/10.1080/089419200750035610

McConnell, W. J., J. D. A. Millington, N. J. Reo, M. Alberti, H. Asbjornsen, L. A. Baker, N. Brozovic, L. E. Drinkwater, S. A. Drzyzga, J. Fragoso, D. S. Holland, C. A. Jantz, T. A. Kohler, H. D. G. Maschner, M. Monticino, G. Podestá, R. G. Pontius Jr., C. L. Redman, D. Sailor, G. Urquhart, and J. Liu. 2011. Research on coupled human and natural systems (CHANS): approach, challenges, and strategies. Bulletin of the Ecological Society of America 92(2):218-228. http://dx.doi.org/10.1890/0012-9623-92.2.218

McLean, J. 1999. Conservation and the impact of relocation on the Tharus of Chitwan, Nepal. Himalaya 19(2): 8. [online] URL: http://digitalcommons.macalester.edu/himalaya/vol19/iss2/8.

McNeely, J. A., and P. S. Sochaczewski. 1991. Soul of the tiger: searching for nature's answers in Southeast Asia. University of Hawaii Press, Honolulu, Hawaii, USA.

Montgomery, M. R. 2008. The urban transformation of the developing world. Science 319:761-764. http://dx.doi.org/10.1126/ science. 1153012

Müller-Böker, U. 1991. Knowledge and evaluation of the environment in traditional societies of Nepal. Mountain Research and Development 11(2):101-114. http://dx.doi.org/10.2307/3673570

Myers, N., R. A. Mittermeier, C. G. Mittermeier, G. A. B. da Fonseca, and J. Kent. 2000. Biodiversity hotspots for conservation priorities. Nature 403:853-858. http://dx.doi.org/10.1038/35002501

Nagendra, H., M. Karmacharya, and B. Karna. 2005. Evaluating forest management in Nepal: views across space and time. Ecology and Society 10(1): 24. [online] URL: http://www.ecologyandsociety. org/vol10/iss 1/art24/.

Nagendra, H., S. Pareeth, B. Sharma, C. M. Schweik, and K. R. Adhikari. 2008. Forest fragmentation and regrowth in an institutional mosaic of community, government and private ownership in Nepal. Landscape Ecology 23(1):41-54. http://dx. doi.org/10.1007/s10980-007-9162-y

Nepal Central Bureau of Statistics. 2014. National population and housing census 2011 (Village Development Committeel municipality): Chitwan. National Planning Commission Secretariat, Government of Nepal, Kathmandu, Nepal. [online] URL: http://cbs.gov.np/wp-content/uploads/2014/04/35\%

20Chitwan VDCLevelReport.pdf.

Nepal, S. K., and K. E. Weber. 1995a. The quandary of local people-Park relations in Nepal's Royal Chitwan National Park. Environmental Management 19(6):853-866. http://dx.doi.org/10.1007/ BF02471937

Nepal, S. K., and K. E. Weber. 1995b. Prospects for coexistence: wildlife and local people. Ambio 24:238-245.

Nowell, K. 2012. Wildlife crime scorecard: assessing compliance with and enforcement of CITES committments for tigers, rhinos and elephants. WWF Report. WWF, Gland, Switzerland. [online] URL: http://awsassets.panda.org/downloads/wwf wildlife crime scorecard report.pdf.

Ostrom, E. 2009. A general framework for analyzing sustainability of social-ecological systems. Science 325:419-422. http://dx.doi.org/10.1126/science.1172133

Palmer, M. A. 2012. Socioenvironmental sustainability and actionable science. BioScience 62(1):5-6. http://dx.doi.org/10.1525/ bio.2012.62.1.2

Peet, N. B., A. R. Watkinson, D. J. Bell, and B. J. Kattel. 1999. Plant diversity in the threatened sub-tropical grasslands of Nepal. Biological Conservation 88(2):193-206. http://dx.doi.org/10.1016/ S0006-3207(98)00104-9

Peterson, M. N., X. Chen, and J. Liu. 2008. Household location choices: implications for biodiversity conservation. Conservation Biology 22(4):912-921. http://dx.doi.org/10.1111/j.1523-1739.2008.00929. $\underline{\mathrm{X}}$

Peterson, M. N., T. R. Peterson, and J. Liu. 2013. The housing bomb: why our addiction to houses is destroying the environment and threatening our society. Johns Hopkins University Press, Baltimore, Maryland, USA.

Ran, J. 2003. Habitat selection by giant pandas and grazing livestock in the Xiaoxiangling Mountains of Sichuan Province. Journal of Sun Yatsen University Social Science Edition 23:2253-2259.

Reid, D. G., and J. Hu. 1991. Giant panda selection between Bashania fangiana bamboo habitats in Wolong Reserve, Sichuan, China. Journal of Applied Ecology 28(1):228-243. http://dx.doi. org/10.2307/2404127

Reid, D. G., and G. Jien. 1999. Giant panda conservation action plan. Pages 241-254 in C. Servheen, S. Herrero, and B. Peyton, editors. Bear: status survey and conservation action plan. IUCN/ SSC Bear and Polar Bear Specialist Groups, IUCN, Gland, Switzerland.

Ricciardi, A., W. W. M. Steiner, R. N. Mack, and D. Simberloff. 2000. Toward a global information system for invasive species. 
BioScience 50(3):239-244. http://dx.doi.org/10.1641/0006-3568 (2000)050[0239:TAGISF]2.3.CO;2

Rindfuss, R. R., B. Entwisle, S. J. Walsh, L. An, N. Badenoch, D. G. Brown, P. Deadman, T. P. Evans, J. Fox, J. Geoghegan, M. Gutmann, M. Kelly, M. Linderman, J. Liu, G. P. Malanson, C. F. Mena, J. P. Messina, E. F. Moran, D. C. Parker, W. Parton, P. Prasartkul, D. T. Robinson, Y. Sawangdee, L. K. Vanwey, and P. H. Verburg. 2008. Land use change: complexity and comparisons. Journal of Land Use Science 3(1):1-10. http://dx.doi. org/10.1080/17474230802047955

Ripple, W. J., J. A. Estes, R. L. Beschta, C. C. Wilmers, E. G. Ritchie, M. Hebblewhite, J. Berger, B. Elmhagen, M. Letnic, M. P. Nelson, O. J. Schmitz, D. W. Smith, A. D. Wallach, and A. J. Wirsing. 2014. Status and ecological effects of the world's largest carnivores. Science 343: 1241484. http://dx.doi.org/10.1126/ science. 1241484

Roberge, J.-M., and P. Angelstam. 2004. Usefulness of the umbrella species concept as a conservation tool. Conservation Biology 18(1):76-85. http://dx.doi.org/10.1111/j.1523-1739.2004.00450. $\underline{\mathrm{x}}$

Roy, E. D., A. T. Morzillo, F. Seijo, S. M. W. Reddy, J. M. Rhemtulla, J. C. Milder, T. Kuemmerle, and S. L. Martin. 2013. The elusive pursuit of interdisciplinarity at the humanenvironment interface. BioScience 63(9):745-753. http://dx.doi. org/10.1093/bioscience/63.9.745

Sapkota, L. 2007. Ecology and management issues of Mikania micrantha in Chitwan Naitonal Park, Nepal. Banko Janakari 17 (2):27-39.

Sayer, J. A., and C. Sun. 2003. Impacts of policy reforms on forest environments and biodiversity. Pages 177-194 in W. F. Hyde, B. Belcher, and J. Xu, editors. China's forests: global lessons from market reforms. Resources for the Future, Washington, D.C., USA.

Schaller, G. B. 1993. The last panda. University of Chicago Press, Chicago, Illinois, USA.

Schaller, G. B., J. Hu, W. Pan, and J. Zhu. 1985. The giant pandas of Wolong. University of Chicago Press, Chicago, Illinois, USA.

Sharma, U. R. 1990. An overview of park-people interactions in Royal Chitwan National Park, Nepal. Landscape and Urban Planning 19(2):133-144. http://dx.doi.org/10.1016/0169-2046(90) $\underline{90049-8}$

Shivakoti, G. P., W. G. Axinn, P. Bhandari, and N. B. Chhetri. 1999. The impact of community context on land use in an agricultural society. Population and Environment 20(3):191-213. http://dx.doi.org/10.1023/A:1023398907307

Sichuan Statistics Bureau. 2008. Sichuan statistical yearbook 2007. China Statistics Press, Beijing, China.

Skogen, K., I. Mauz, and O. Krange. 2008. Cry wolf!: Narratives of wolf recovery in France and Norway. Rural Sociology 73 (1):105-133. http://dx.doi.org/10.1526/003601108783575916

Smith, J. L. D., S. C. Ahern, and C. McDougal. 1998. Landscape analysis of tiger distribution and habitat quality in Nepal. Conservation Biology 12(6):1338-1346. http://dx.doi.org/10.1111/ j.1523-1739.1998.97068.x
Smythies, E. A. 1942. Big game shooting in Nepal: with leaves from the Maharaja's sporting diary. Thacker, Calcutta, India.

Spiteri, A., and S. K. Nepal. 2008. Distributing conservation incentives in the buffer zone of Chitwan National Park, Nepal. Environmental Conservation 35(1):76-86. http://dx.doi.org/10.1017/ $\underline{\mathrm{S} 0376892908004451}$

State Forestry Administration. 2006. The third national survey report on the giant panda in China. [In Chinese]. Science Publishing House, Beijing, China.

Steinfeld, H., P. Gerber, T. Wassenaar, V. Castel, M. Rosales, and C. de Haan. 2006. Livestock's long shadow: environmental issues and options. FAO, Rome, Italy. [online] URL: http://www.fao.org/ docrep/010/a0701e/a0701e00.HTM.

Stræde, S., and F. Helles. 2000. Park-people conflict resolution in Royal Chitwan National Park, Nepal: buying time at high cost? Environmental Conservation 27(4):368-381. http://dx.doi.org/10.1017/ $\underline{\mathrm{S} 0376892900000424}$

Stræde, S., and T. Treue. 2006. Beyond buffer zone protection: a comparative study of park and buffer zone products' importance to villagers living inside Royal Chitwan National Park and to villagers living in its buffer zone. Journal of Environmental Management 78(3):251-267. http://dx.doi.org/10.1016/j. jenvman.2005.03.017

Studley, J. 1999. Forests and environmental degradation in SW China. International Forestry Review 1:260-265.

Sunarto, S., M. J. Kelly, K. Parakkasi, S. Klenzendorf, E. Septayuda, and H. Kurniawan. 2012. Tigers need cover: multiscale occupancy study of the big cat in Sumatran forest and plantation landscapes. PLoS One 7: e30859. http://dx.doi. org/10.1371/journal.pone.0030859

Sunquist, M., K. U. Karanth, and F. Sunquist. 1999. Ecology, behaviour and resilience of the tiger and its conservation needs. Pages 5-18 in J. Seidensticker, S. Christie, and P. Jackson, editors. Riding the tiger: tiger conservation in human-dominated landscapes. Cambridge University Press, Cambridge, UK.

Taylor, A. H., and Z. Qin. 1993. Bamboo regeneration after flowering in the Wolong Giant Panda Reserve, China. Biological Conservation 63(3):231-234. http://dx.doi.org/10.1016/0006-3207 (93)90717-F

Terborgh, J., J. A. Estes, P. Paquet, K. Ralls, D. Boyd-Heger, B. J. Miller, and R. F. Noss. 1999. The role of top carnivores in regulating terrestrial ecosystems. Pages 39-64 in M. E. Soulé and J. Terborgh, editors. Continental conservation: scientific foundations of regional reserve networks. Island Press, Washington, D.C., USA.

Theobald, D. M., J. R. Miller, and N. T. Hobbs. 1997. Estimating the cumulative effects of development on wildlife habitat. Landscape and Urban Planning 39(1):25-36. http://dx.doi. org/10.1016/S0169-2046(97)00041-8

Tigas, L. A., D. H. van Vuren, and R. M. Sauvajot. 2002. Behavioral responses of bobcats and coyotes to habitat fragmentation and corridors in an urban environment. Biological Conservation 108(3):299-306. http://dx.doi.org/10.1016/S0006-3207 (02)00120-9 
Treves, A., R. B. Wallace, L. Naughton-Treves, and A. Morales. 2006. Co-managing human-wildlife conflicts: a review. Human Dimensions of Wildlife 11(6):383-396. http://dx.doi. org/10.1080/10871200600984265

Tuanmu, M.-N., A. Viña, S. Bearer, W. Xu, Z. Ouyang, H. Zhang, and J. Liu. 2010. Mapping understory vegetation using phenological characteristics derived from remotely sensed data. Remote Sensing of Environment 114(8):1833-1844. http://dx.doi. org/10.1016/j.rse.2010.03.008

Tuanmu, M.-N., A. Viña, G. J. Roloff, W. Liu, Z. Ouyang, H. Zhang, and J. Liu. 2011. Temporal transferability of wildlife habitat models: implications for habitat monitoring. Journal of Biogeography 38(8):1510-1523. http://dx.doi.org/10.1111/ j.1365-2699.2011.02479.x

Turner, B. L. III, P. A. Matson, J. J. McCarthy, R. W. Corell, L. Christensen, N. Eckley, G. K. Hovelsrud-Broda, J. X. Kasperson, R. E. Kasperson, A. Luers, M. L. Martello, S. Mathiesen, R. Naylor, C. Polsky, A. Pulsipher, A. Schiller, H. Selin, and N. Tyler. 2003. Illustrating the coupled human-environment system for vulnerability analysis: three case studies. Proceedings of the National Academy of Sciences 100(14):8080-8085. http://dx.doi. org/10.1073/pnas.1231334100

UNESCO/IUCN. 2003. UNESCO-IUCN enhancing our heritage project: monitoring and managing for success in natural world heritage sites. Initial management effectiveness evaluation report: Royal Chitwan National Park, Nepal. IUCN, Gland, Switzerland. [online] URL: http://whc.unesco.org/document/6957.

Valeix, M., G. Hemson, A. J. Loveridge, G. Mills, and D. W. Macdonald. 2012. Behavioural adjustments of a large carnivore to access secondary prey in a human-dominated landscape. Journal of Applied Ecology 49(1):73-81. http://dx.doi. org/10.1111/j.1365-2664.2011.02099.X

Viña, A., S. Bearer, X. Chen, G. He, M. Linderman, L. An, H. Zhang, Z. Ouyang, and J. Liu. 2007. Temporal changes in giant panda habitat connectivity across boundaries of Wolong Nature Reserve, China. Ecological Applications 17(4):1019-1030. http:// dx.doi.org/10.1890/05-1288

Viña, A., S. Bearer, H. Zhang, Z. Ouyang, and J. Liu. 2008. Evaluating MODIS data for mapping wildlife habitat distribution. Remote Sensing of Environment 112(5):2160-2169. http://dx.doi.org/10.1016/j.rse.2007.09.012

Viña, A., X. Chen, W. J. McConnell, W. Liu, W. Xu, Z. Ouyang, H. Zhang, and J. Liu. 2011. Effects of natural disasters on conservation policies: the case of the 2008 Wenchuan Earthquake, China. Ambio 40(3):274-284. http://dx.doi.org/10.1007/s13280-010-0098-0

Viña, A., M.-N. Tuanmu, W. Xu, Y. Li, Z. Ouyang, R. DeFries, and J. Liu. 2010. Range-wide analysis of wildlife habitat: implications for conservation. Biological Conservation 143 (9):1960-1969. http://dx.doi.org/10.1016/j.biocon.2010.04.046

Walker, B., C. S. Holling, S. R. Carpenter, and A. Kinzig. 2004. Resilience, adaptability and transformability in social-ecological systems. Ecology and Society 9(2): 5. [online] URL: http://www. ecologyandsociety.org/vol9/iss2/art5/.
Wang, W., S. B. Franklin, and J. R. Ouellette. 2007. Clonal regeneration of an arrow bamboo, Fargesia qinlingensis, following giant panda herbivory. Plant Ecology 192(1):97-106. http://dx. doi.org/10.1007/s11258-006-9229-X

Wenguang, Z., H. Yuanman, H. Jinchu, C. Yu, Z. Jing, and L. Miao. 2008. Impacts of land-use change on mammal diversity in the upper reaches of Minjiang River, China: implications for biodiversity conservation planning. Landscape and Urban Planning 85(3-4):195-204. http://dx.doi.org/10.1016/j. landurbplan.2007.11.006

Wittemyer, G., P. Elsen, W. T. Bean, A. C. O. Burton, and J. S. Brashares. 2008. Accelerated human population growth at protected area edges. Science 321:123-126. http://dx.doi. org/10.1126/science. 1158900

Wolong Administration Bureau. 2004. The history of Wolong Nature Reserve. [In Chinese]. Sichuan Science and Technology Press, Chengdu, China.

Xu, W., Z. Ouyang, A. Viña, H. Zheng, J. Liu, and Y. Xiao. 2006. Designing a conservation plan for protecting the habitat for giant pandas in the Qionglai mountain range, China. Diversity and Distributions 12(5):610-619. http://dx.doi.org/10.1111/ j.1366-9516.2006.00236.x

Yang, W., T. Dietz, W. Liu, J. Luo, and J. Liu. 2013a. Going beyond the Millennium Ecosystem Assessment: an index system of human dependence on ecosystem services. PLoS One 8: e64581. http://dx.doi.org/10.1371/journal.pone.0064581

Yang, W., W. Liu, A. Viña, M.-N. Tuanmu, G. He, T. Dietz, and J. Liu. 2013b. Nonlinear effects of group size on collective action and resource outcomes. Proceedings of the National Academy of Sciences 110(27):10916-10921. http://dx.doi.org/10.1073/pnas.1301733110

Young, T. P., T. M. Palmer, and M. E. Gadd. 2005. Competition and compensation among cattle, zebras, and elephants in a semiarid savanna in Laikipia, Kenya. Biological Conservation 122 (2):351-359. http://dx.doi.org/10.1016/j.biocon.2004.08.007 